\title{
Hypericum genus cosmeceutical application - A decade comprehensive review on its multifunctional biological properties
}

\author{
Ana Rita Silva ${ }^{\mathrm{a}, \mathrm{b}}$, Oludemi Taofiq ${ }^{\mathrm{a}}$, Isabel C.F.R. Ferreira ${ }^{\mathrm{a}}$, Lillian Barros ${ }^{\mathrm{a}, *}$ \\ ${ }^{\text {a } C e n t r o ~ d e ~ I n v e s t i g a c ̧ a ̃ o ~ d e ~ M o n t a n h a ~(C I M O), ~ I n s t i t u t o ~ P o l i t e ́ c n i c o ~ d e ~ B r a g a n c ̧ a, ~ C a m p u s ~ d e ~ S a n t a ~ A p o l o ́ n i a, ~ 5300-253 ~ B r a g a n c ̧ a, ~ P o r t u g a l ~}$ \\ ${ }^{\mathrm{b}}$ Departamento de Ciencias Farmacéuticas, Facultad de Farmacia, CIETUS-IBSAL, Universidad de Salamanca, 37007 Salamanca, Spain
}

\section{A R T I C L E I N F O}

\section{Keywords:}

Hypericum genus

Hypericum perforatum

Bioactive compounds

Biological properties

Cosmeceutical application

\begin{abstract}
A B S T R A C T
Hypericum is a genus of flowering plants and presents a nearly worldwide distribution. The relevance of its species is mainly based on the occurrence of specialised secondary metabolites exhibiting a wide range of pharmaceutical and cosmeceutical properties. The most well-reported species in the last decade is $H$. perforatum, together with its exceptional polycyclic polyprenylated acylphloroglucinols metabolites. Several inhibitory enzyme properties such as anti-tyrosinase, anti-hyaluronidase, anti-collagenase, and anti-elastase, along with the relevant cosmeceutical anti-inflammatory and antimicrobial activities, have been reported in numerous biological studies concerning this genus. From 2010 to date were published more than 3000 articles; therefore, an updated summary of Hypericum species and their related cosmeceutical bioactive compounds is necessary. This detailed analysis will be mainly focused on cosmeceutical-related bioactivity, phytochemical composition, and the products and processes that have been developed using the generated knowledge. Despite all the progress made in recent years, which contributed to a state-of-the-art improvement, only a few studies regarding the genus have been dedicated to investigating the mechanisms of action and the safety (toxicology) of its bioactive compounds using well-validated methodologies. A strategic partnership between R\&D and vital cosmeceutical enterprises could be the requisite to promote the development of a higher number of efficient and marketable Hypericum-derived cosmeceutical products.
\end{abstract}

\section{Introduction}

The ancient science of cosmetology is believed to have its origins in Egypt and India, as the earliest documented practises using cosmeceuticals date back to the Indus valley civilization, circa 2500 and 1550 B.C (Charles Dorni et al., 2017). The term cosmeceutical is commonly used to define a cosmetic product with active ingredients promoting drug-like benefits (Dominguez et al., 2017; Lee, 2016). They are applied topically and include creams, lotions, and ointments, functionalised with active compounds known to influence the biological function of the skin by supplying the needed antioxidants while improving its appearance, radiance, texture, and anti-ageing activity (Lee, 2016; Taofiq et al., 2016a). Plant-derived compounds have been extensively used for cosmeceutical applications, mainly due to the investigation of the active principles behind their traditional practices (Charles Dorni et al., 2017). These investigations have led to the publication of an endless number of studies describing the science behind the uses of flowers, seeds, roots, leaves, twigs, and berries from plants distributed worldwide (Charles
Dorni et al., 2017; Lee, 2016). The rising demand for natural products is also the result of increased awareness among consumers, not only related to lifestyle issues and their impact on health and well-being, but also sustainability concerns regarding the origin, safety, and environmental implications of some of the ingredients used in food, nutraceuticals, and cosmetics formulations (Antognoni et al., 2017; Bilal and Iqbal, 2019). Accordingly, the global natural cosmetic market size was estimated at 34.12 Billion USD in 2018, and it is predicted to grow at an estimated rate of $5.01 \%$ from 2019 to 2025 ("Natural Cosmetics Market Size, Share, Trends | Industry Report, 2025," 2019).

The genus Hypericum (Hypericaceae) is one of the 100 largest genera within the angiosperms clade, encompassing over 500 species, which are quite variable in form and habitat, occurring as trees, shrubs, annuals, and perennials (Cirak et al., 2016). Although globally distributed, Hypericum specimens are generally absent from the poles, deserts, and low-altitude tropical areas (Nürk and Crockett, 2011). The healing properties of many of its species are well known and have been mainly attributed to its phytochemicals, namely naphthodianthrones (hypericin

\footnotetext{
* Corresponidng author.

E-mail address: lillian@ipb.pt (L. Barros).
} 
and pseudohypericin), phloroglucinols (hyperforin), flavonoids (rutin, hyperoside, isoquercitrin, quercitrin, quercetin, amentoflavone), and phenylpropanoids (chlorogenic acid) (Cirak et al., 2016; Marrelli et al., 2016). These molecules are behind a great variety of identified bioactivities: antiaging; anti-inflammatory; antimitogenic; antiviral; antiretroviral; antibacterial; antidepressant; photodynamic; and antitumor; among others (Cirak et al., 2016). Although the most extensively studied species within this genus is Hypericum perforatum L., significant attention has been given to some other species, which have been studied regarding their phytochemical composition and related biological activities (Marrelli et al., 2016). The present systematic review intends to critically examine how Hypericum species were evaluated, and summarise the most relevant cosmeceutical data published over the past decade to: provide an overview of the different Hypericum species and their bioactive composition; describe which Hypericum species (and related metabolites) have been explored as skincare ingredients; identify their bioactive properties closely linked to skincare treatments; present a systematic assessment of the in vivo studies conducted using formulations containing compounds from different Hypericum species; describe the safety and toxicity assessment of Hypericum-derived ingredients used as cosmeceuticals; provide an overview of patents and commercial products; and identify future trends and challenges associated with the genus derived cosmeceutical products.

\section{Ethnobotanical uses of the most common species}

\subsection{Hypericum androsaemum $L$}

H. androsaemum L. (Guttiferae) is a Mediterranean medicinal small evergreen shrub occurring in woods dominated by chestnut and oak trees, also known as shrubby St. John's Wort or “Tutsan", meaning 'toutsaine', i.e. 'all-heal', the name was given for its supposed medicinal properties (Valentão et al., 2004). Contrasting to the majority of Hypericum species, which exhibit a dry capsule as a fruit, H. androsaemum produces fleshy berry-like capsules, which turn from red to black as they mature (Antognoni et al., 2017). Another differentiating characteristic of this species is the absence of dark leaf nodules, the secretory structures in which naphtodianthrones are synthesized (Crockett and Robson, 2011), resulting in plant extracts devoid of hypericin and its derivatives (Nabavi et al., 2018). In Portugal it is known as 'Hipericão do Gerês' and has been used for its diuretic, hepatoprotective, and antidepressant effect (Antognoni et al., 2017). Similarly, in Spanish folk medicine, $\mathrm{H}$. androsaemum has been used as an antidepressant and anxiolytic (Nabavi et al., 2018), whereas in England it has been traditionally used to prepare ointments to treat cuts and wounds (Antognoni et al., 2017).

\subsection{Hypericum grandifolium Choisy}

H. grandifolium, also commonly known as 'malfurada', is an endemic species of Azores, Madeira, and the Canaries islands (Rabanal et al., 2002; Sánchez-Mateo et al., 2009). Although prevalent in the Macaronesia region, was also introduced in Australia, New Zeeland, California, Hawaii island, and South Africa. It is an evergreen shrub up to $1.8 \mathrm{~m}$ in height, with dark green leaves, and bright yellow flowers up to $4.5 \mathrm{~cm}$ broad growing in woods as shown in Fig. 1(ii). H. grandifolium and other Hypericum species were used in the folk medicine in the Canary Islands as a vermifuge, diuretic, wound healing, as well as sedative, anti-hysteric, tranquillizer, and antidepressant agents (Darias et al., 1986; Wu et al., 2013).

\subsection{Hypericum monogynum $L$}

H. monogynum is a semi-evergreen shrub with narrow leaves and approximately $6 \mathrm{~cm}$ wide flowers containing visible golden stamens from summer to autumn Fig. 1(iii). Although widely cultivated in South
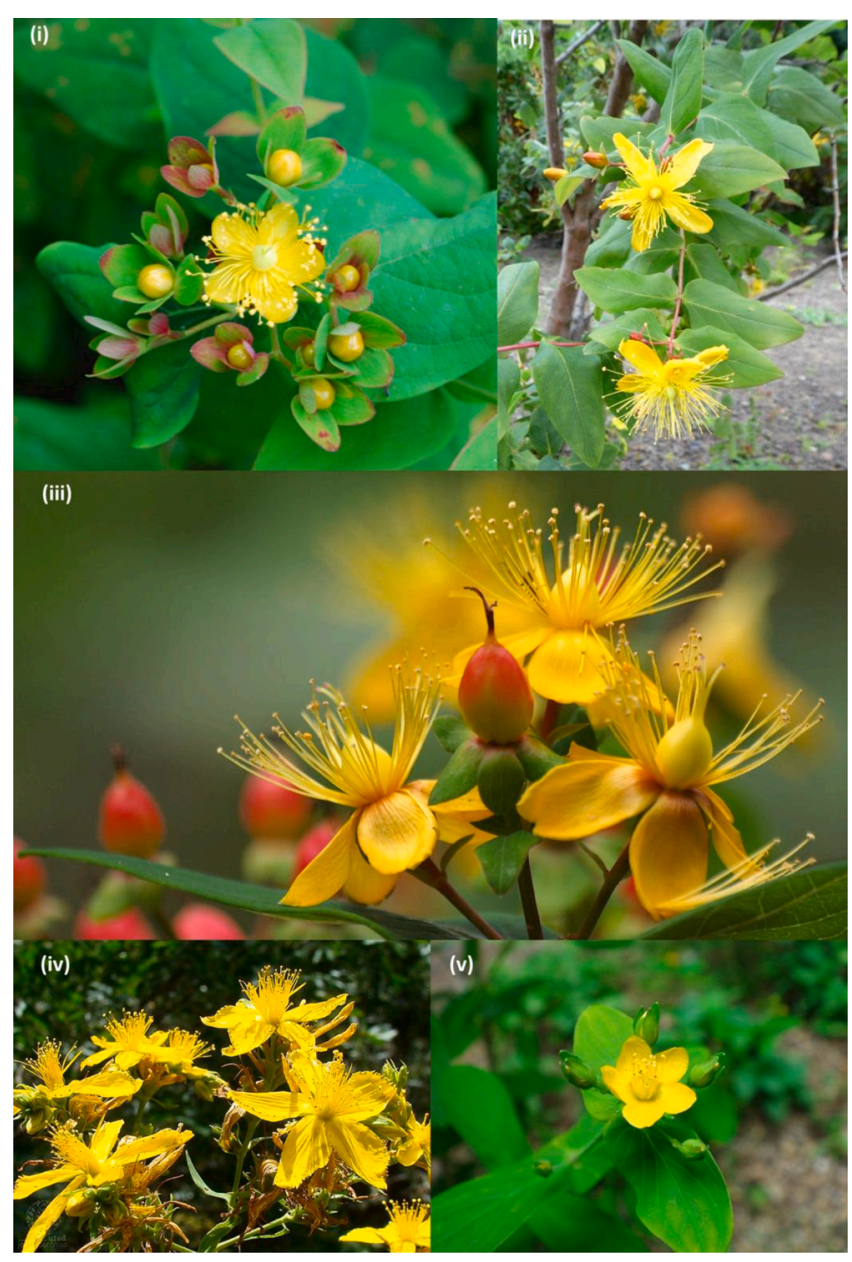

Fig. 1. (i) H. androsaemum (author: Isabel Garcia-Cabral - Botanical Garden UTAD); (ii) H. grandifolium (Botanical Garden Canario Viera y Clavijo - file licensed under the Creative Commons Attribution-Share Alike 4.0 International license); (iii) H. monogynum (adapted from coniferconifer - file licensed under the Creative Commons Attribution 2.0 Generic) (iv) H. perforatum L. (Botanical Garden UTAD; (v) H. sampsonii (Kyoto Botanical Garden).

Africa, east and southern Asia, Australia, Central America, north-west Europe, and Mauritius, it is mainly distributed throughout China and some places of Japan (Ernst, 2003; Li et al., 2020; Tanaka and Takaishi, 2006). As a traditional folk medicine, this plant has been used for the treatment of dysmenorrhea and other female disorders, cough, hypertension, hepatitis, acute laryngopharyngitis, pertussis, conjunctivitis, rheumatic arthritis, bites of venomous animals, and blunt trauma (Tanaka et al., 2005; Tanaka and Takaishi, 2006; Zhang et al., 2020). Besides been widely utilised in Chinese folk medicine to treat various diseases, it is also cultivated as a landscape plant due to its attractive yellow flowers (Xu et al., 2015).

\subsection{Hypericum origanifolium Willd}

H. origanifolium is a herbaceous perennial endemic species to Turkey, Armenia, and Georgia (Yaşar et al., 2013), which grows in grassy communities of rocky hills. Its stems are 5-30 cm long, branching, and sometimes rooting at the base; the leaves are opposite, ovate or obovate, 5-30 $\mathrm{mm}$ in height, with intramarginal and sometimes superficial black glandular dots. This species has numerous golden yellow coloured flowers, forming a broadly paniculate, almost corymbose inflorescence. Its flowers consist of five yellow petals, five green sepals, three styles, and numerous stamens (Çirak et al., 2007). H. origanifolium has great pharmaceutical potential due to its well-documented phenolic and 
hypericin content (Çirak et al., 2007; Ozen et al., 2005). Even though studies have exploited the phytochemical composition of H. origanifolium, details of their pharmacological properties are scarcely available (Bertoli et al., 2015; Yaşar et al., 2013). H. origanifolium has recently been considered as a potential substitute of $H$. perforatum in the well-established EU market due to its potential biological properties (Boran, 2018).

\subsection{Hypericum perforatum $L$}

H. perforatum has a rich historical background, being one of the oldest used and most extensively investigated medicinal herbs. Popularly termed as St. John's wort, it is an herbaceous perennial flowering plant native from Europe, but widely cultivated in temperate regions of Asia, North Africa, North America, and Australia. It usually prospers in poor soils and is found in meadows, fields, waste areas, and roadsides (Galeotti, 2017; Klemow et al., 2011; Öztürk et al., 2007). H. perforatum consists of freely branching shrubby herbs, the stems and branches are densely covered by oblong, smooth-margined leaves that range from 1 to $3 \mathrm{~cm}$ long and $0.3-1.0 \mathrm{~cm}$ wide. The upper portions of mature plants can produce several dozen five-petaled yellow flowers, which edges are usually covered with black dots. During late summer, the flowers produce capsules containing dark-brown seeds (Klemow et al., 2011). As a herbal remedy known since Greek and Roman times, $H$. perforatum has been used to treat: ulcers; diabetes mellitus; common cold; gastrointestinal disorders; jaundice; hepatic and biliary disorders; hemoptysis; hematemesis; metrorrhagia; traumatic haemorrhage; irregular menstruation; acute mastitis; sore throat; swelling and pain of the eye; urinary tract infection; sore furuncle; burns; wounds and bruises; and rheumatic arthritis (Galeotti, 2017; Klemow et al., 2011; Öztürk et al., 2007; Süntar et al., 2010; Zhang et al., 2020).

\subsection{Hypericum sampsonii Hance}

H. sampsonii is found by the river Yangtze in southern China, North Vietnam, eastern Burma, Myanmar, northeast India, and Japan (Liu et al., 2007; Zhang et al., 2017). It is a perennial herb $20-80 \mathrm{~cm}$ tall with perfoliate leaves; its flowers present $30-42$ stamens and are visible between June and October. As a traditional Chinese medicine, H. sampsonii is known as "Yuanbao Cao" and has been used in the treatment of haemoptysis, hepatic disorders, epistaxis, metrorrhagia, traumatic haemorrhage, menstrual cramps, irregular menstruation, dysmenorrhea, acute mastitis, sore furuncle, dysentery, enteritis, snake bite, burn, wounds, bruises, arthralgia, myalgia, fever, and various inflammation-related diseases (Chen et al., 2014, 2020; Liu et al., 2007; Zhang et al., 2020). In Vietnam, it is an important medicinal plant used in to treat many diseases such as backache, burns, diarrhoea, and swelling, due to its high content in xanthones and benzophenones (Nguyen Viet et al., 2019).

\section{Major biologically active components}

The cosmeceutical and pharmaceutical importance of this genus is due to the presence of a broad spectrum of specialized bioactive compounds such as naphthodianthrones (Jarić et al., 2018), phloroglucinols (Nogueira et al., 2013), flavonoids (Antognoni et al., 2017), phenolic acids, and related compounds (López et al., 2016). A minute amount of other biomolecules such as tannins, xanthones, triterpenes, and volatile organic compounds have also been reported to be present in some Hypericum species (Ersoy et al., 2019).

\subsection{Naphthodianthrones}

Typically found in Hypericum species, naphthodianthrones are compounds characterised by intense red colour and exhibiting several biological properties mediated by different mechanisms of action (Germ et al., 2010; Mansour et al., 2014; Süntar et al., 2011). Hypericins are the most well-reported compounds of this class. The two proto-derivatives protohypericin and pseudoprotohypericin, have also been found in several Hypericum species, but due to their unstable nature are easily converted to hypericin and pseudohypericin, respectively (Saddiqe et al., 2010). Hypericin and pseudohypericin, shown in Fig. 2(iii) and (vi), were first isolated from $H$. perforatum $L$., considered the most commercially relevant representative of the genus. These compounds are most abundant in flowers and leaves, with concentrations ranging from $0.03 \%$ to $0.3 \%$ of dry weight, which can significantly vary depending on the developmental stage of the plant, cultivar, altitude, light conditions, origin, and season (Karioti and Bilia, 2010). $H$. perforatum flowering plants from Lithuania showed between 770-1990 $\mu$ g hypericin/g DW (Bagdonaitž et al., 2010), while samples from Slovakia presented a lower amount, $50 \mu \mathrm{g}$ hypericin/g DW (Dresler et al., 2018). Although naphthodianthrones show limited solubility in almost all solvents, pseudohypericin presents higher solubility in polar solvents, which is mainly attributed to the presence of an additional hydroxymethyl moiety (Saddiqe et al., 2010). Higher solubility of hypericin and pseudo-hypericin has been associated with the addition of potassium salts during the extraction process. This mechanochemical treatment also increases the dissolution rates, which allow higher extraction yield of the active substances (Karioti and Bilia, 2010; Lomovsky et al., 2017).

\subsection{Phloroglucinols}

The phloroglucinols are among the most prominent secondary metabolites of the Hypericum genus, being the polycyclic polyprenylated acylphloroglucinols (PPAPs), formed by the hybridization of the mevalonate/methylerythritol phosphate and polyketide biosynthetic pathways, the most abundant compounds (Ye et al., 2020). They exhibit fascinating chemical structures, with well-reported biological activities, such as anti-HIV, antidepressant, antibacterial, antimalarial, antioxidant, anti-neurodegenerative, antiulcer, wound healing, and anti-inflammatory (Zhou et al., 2014). The bicyclic prenylated phloroglucinol derivative hyperforin, represented in Fig. 2(v), is one of the main bioactive compounds present in Hypericum species. It is mainly distributed in their reproductive parts, approximately $2 \%$ in the flowers, $4.4 \%$ in the ripe fruits, and $4.5 \%$ in the unripe fruits (Saddiqe et al., 2010). This compound is highly lipophilic, sensitive against air oxidation, and unstable in most organic solvents (Füller and Müller-Goymann, 2018). Similarly, many meroterpenoids presenting impressive chemical structures biogenetically related to prenylated acylphloroglucinols, such as Hyperinoids A and B, and Hyperbeanols A, B, and F, have been identified in some Hypericum species (Jia et al., 2019; Li et al., 2019a; Xu et al., 2019).

\subsection{Phenolic compounds}

\subsubsection{Phenolic acids and related compounds}

Among the various phenolic acids found in Hypericum species, chlorogenic acid is the most abundant and widely identified (Kladar et al., 2015; Tusevski et al., 2014). Other phenolic acids such as ferulic, cryptochlorogenic, neochlorogenic, quinic, 3-p-coumaroylquinic, gallic, caffeic, sinapic and 3-feruloylquinic acid, have also been identified in $H$. richeri, $H$. perforatum, $H$. lanuginosum, $H$. perfoliatum, $H$. barbatum, $H$. japonicum, $H$. hirsutum, H. androsaemum, and H. acutum species (Celep et al., 2017; Mahomoodally et al., 2019; Nabavi et al., 2018; Zdunic et al., 2017). These compounds are responsible for the hepatoprotective properties, anti-depressive-like effects, and the in vivo antioxidant activity (López et al., 2016; Nabavi et al., 2018), associated with most Hypericum species.

\subsubsection{Flavonoids}

Flavonoids are also among the most significant group of biologically 
<smiles>O=C(/C=C/c1ccc(O)c(O)c1)O[C@H]1C[C@@](O)(C(=O)O)C[C@H](O)[C@H]1O</smiles>

(i)

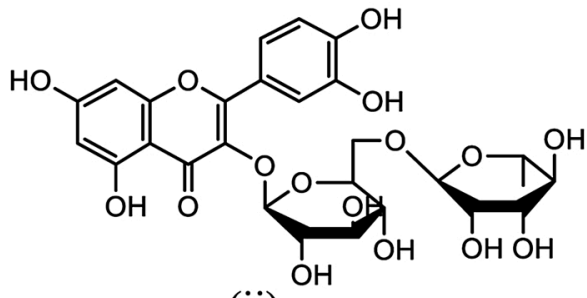

(ii)<smiles></smiles>

(iii)<smiles>O=c1c(O[C@@H]2O[C@H](CO)[C@@H](O)[C@H](O)[C@H]2O)c(-c2ccc(O)c(O)c2)oc2cc(O)cc(O)c12</smiles>

(iv)

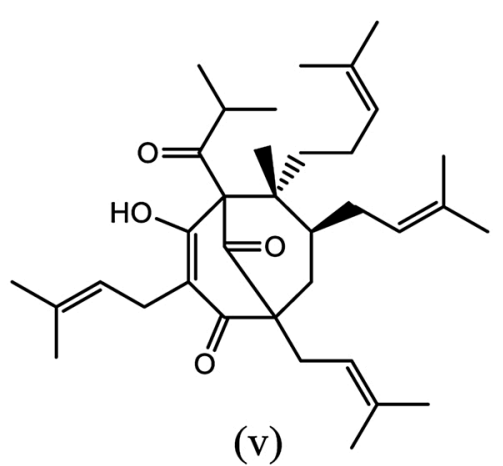

(v)<smiles>Cc1cc(O)c2c(=O)c3c(O)cc(O)c4c5c(O)cc(O)c6c(=O)c7c(O)cc(CO)c8c1c2c(c34)c(c65)c78</smiles>

(vi)

Fig. 2. The most common bioactive compounds found in Hypericum species: (i) chlorogenic acid, (ii) rutin, (iii) hypericin, (iv) hyperoside, (v) hyperforin, (vi) pseudohypericin.

active molecules in Hypericum species, representing up to $2-4 \%$ in some H. perforatum extracts. The most widely identified flavonoids in Hypericum species with well-documented biological activities include kaempferol, luteolin, myricetin, apigenin, quercetin, rutin, quercitrin, isoquercitrin, and biapigenin, among others (Mahomoodally et al., 2019; Nabavi et al., 2018; Napoli et al., 2018). They have attracted much interest in recent years due to their well-reported contribution to the cosmeceutical properties of some Hypericum species (Antognoni et al., 2017; Ersoy et al., 2019). These compounds, mainly present in the leaves, flowers, and fruits, have also been reported to possess strong UV absorbing properties and can mitigate the effects of free radicals (Germ et al., 2010).

\subsubsection{Other minor phenolics}

Xanthones are present in some Hypericum species and have been reported to be among the most important contributors to the cytotoxic, antioxidant, antimicrobial, and anti-inflammatory activities (Li et al., 2013; Zhang et al., 2020). Some common xanthones and their associated derivatives include: mangiferin, garcinone $\mathrm{C}$ and $\mathrm{E}$, banaxanthone $\mathrm{E}$, mangostin isomer, neolancerin, ferrxanthone, brasilixanthone $\mathrm{B}$, and trihydroxy-1-methoxy-C-prenyl (Li et al., 2013; Tusevski et al., 2014). Recently, increasing attention has been given to these compounds due to their monoamine oxidase inhibitory effect and their pharmaceutical potential as an antidepressant drug (Carradori et al., 2014; Takao et al., 2019).

Tannins are one of the most structurally diverse polyphenols present in plants and have been reported to play a vital role in plant defence against microbial pathogens, herbivores, and climatic changes (Silva et al., 2020). Compounds such as gallotannins and tannic acid have been associated with the anti-hyaluronidase activity in Hypericum plants due to tannins well-known strong protein interaction (Ersoy et al., 2019).

\section{Hypericum species cosmeceutical properties}

Numerous extracts and isolated compounds obtained from Hypericum species have been investigated as ingredients for cosmeceutical development. The interactions between cosmeceuticals and skin are complex, depending on the selected concentration of the bioactive components, condition of the skin, absorption, as well as external environmental conditions (Gao et al., 2008). Therefore, in-depth studies to evaluate the multifunctional cosmeceutical properties of the active molecules, together with the disclosure of the mechanism of action, safety, and stability, are an essential prerequisite for specific cosmeceutical products development. The following section reviews the most relevant studies regarding Hypericum spp. multifunctional properties.

\subsection{Antioxidant activity}

Free radicals, generated within the natural metabolism of aerobic cells, can be defined as atoms, molecules, or ions with unpaired electrons, which are capable of independent existence. Its odd number of electron(s) makes it unstable, short-lived, and highly reactive. Reactive species include both free radicals and some other non-radical compounds of oxygen (ROS) and nitrogen (RNS). These species are generated during metabolic processes in the mitochondria or peroxisomes; through xanthine oxidase activity; inflammation processes; phagocytosis; arachidonate pathway; ischemia; and physical exercise. Smoking; environmental pollutants; ultraviolet radiation (UVR); drugs; and pesticides are some examples of external factors that can also promote their formation (Barros et al., 2016; Carocho and Ferreira, 2013; Ferreira et al., 2009). 'Primary' reactive species can interact with other molecules and quickly generate 'secondary' reactive species, which depending on their final concentration within the cell can cause both, oxidative damage or cellular physiological regulation (redox signalling) (Barros et al., 2016; Fernández-Moriano et al., 2016; Phaniendra et al., 2015). Low reactive species levels can directly modulate the activity of transcriptional factors, such as NF- $\mathrm{kB}, \mathrm{p} 53$, NRF2, and induce numerous protein kinase cascades that participate in the regulation of the crosstalk between autophagy, apoptosis, and regeneration. Moreover, beneath physiological conditions, the number of reactive species generated can be counterbalanced by external and internal sources of antioxidants. Endogenous antioxidant defences can be both non-enzymatic (e.g., uric 
acid, glutathione, bilirubin, thiols, albumin, and nutritional factors, including vitamins, and phenols) and enzymatic (e.g., superoxide dismutase, glutathione peroxidase, and catalase) (Ganceviciene et al., 2012; Sharma et al., 2015).

Contrarily to redox signalling, tissue oxidative damage and consequent possible dysfunction is defined as a pathological state in which an imbalance between the biochemical processes leading to the production of ROS and RNS, and those responsible for its removal, occurs (Di Meo et al., 2016; Fernández-Moriano et al., 2016). ROS include species such as the hydroxyl radical $\left(\mathrm{OH}^{*}\right)$, whose reactivity is so high that it reacts very close to its site of formation, and other species, such as superoxide $\left(\mathrm{O}_{2}^{-}\right)$and hydrogen peroxide $\left(\mathrm{H}_{2} \mathrm{O}_{2}\right)$, which are less reactive. RNS include nitric oxide $\left(\mathrm{NO}^{\bullet}\right)$, which is relatively unreactive, and its derivative, the peroxynitrite $\left(\mathrm{ONOO}^{-}\right)$, a powerful oxidant, able to damage many biological molecules (Barros et al., 2016; Di Meo et al., 2016). According to the oxidative damage theory of ageing, it is supposed that longevity could be extended by activation of endogenous antioxidant defence systems or by exogenous antioxidant supplementation; however, excessive doses of these substances may be toxic due to their pro-oxidative effects at high concentrations or their potential to eliminate beneficial levels of reactive species (Vaiserman et al., 2016). This hypothesis supposes that ROS and other reactive species may result in damaged molecules such as carbonylated proteins, lipid peroxides, and oxidised DNA (Liu et al., 2014; Pinto and Moraes, 2015; Vaiserman et al., 2016).

As an interface organ, the skin is particularly vulnerable to environmental insults due to continuous exposure to a complex blend of intrinsic and extrinsic ageing processes. Despite the numerous defence mechanisms to protect the skin from damage, the efficacy of these diminishes over time, resulting in the clinical features associated with ageing and in more severe cases, the development of skin cancers. Bioactive plant derived-compounds can modulate essential cell processes through a vast number of mechanisms of action and interaction points across many intracellular signalling cascades (García-Pérez et al., 2018). Several publications have identified different Hypericum species as important sources of antioxidant molecules presenting capacity as radical scavengers, metal chelators, and lipid peroxidation inhibitors. Some of the most widely utilised antioxidant assays are the DPPH (2, 2-diphenyl-1-picrylhydrazyl), ABTS (2,20-azinobis 3-ethylbenzothiazoline-6-sulfonic acid), FRAP (ferric reducing antioxidant power), CUPRAC (cupric ion reducing antioxidant capacity), TBARS (thiobarbituric acid reactive substances), ORAC (oxygen radical antioxidant capacity), DMPD (N,N-dimethyl-p-phenylenediamine dihydrochloride) TEAC (Trolox-equivalent antioxidant capacity), and the superoxide anion radical scavenging assay. Eleven Hypericum species grown in Sicily $(H$. perforatum, H. aegypticum L., H. androsaemum, $H$. calycinum L., $H$. hircinum L., H. hirsutum L., H. montanum L., H. patulum, $H$. perfoliatum L., H. pubescens Boiss., and $H$. tetrapterum Fr.) were reported to have a good level of antioxidant/radical scavenging activity, with $H$. perforatum extract ( $1.03 \pm 0.19 \mathrm{mmol}$ Trolox equivalent/g) being the most active during the ORAC assay. Moreover, $H$. aegypticum extract presented the best DPPH scavenging activity $(0.57 \pm 0.24 \mathrm{mmol}$ Trolox equivalent/g) (Napoli et al., 2018). Hyperforin and hypericin are the main bioactive molecules present across the Hypericum genus. However, other constituents, like the polyphenols, have also been reported to be the main responsible for their potent antioxidant properties. Napoli et al. (2018) attributed the antioxidant capacities of Hypericum species to their high content in polyphenolic compounds like apigenin, amentoflavone, quercetin-3-O-glucoside, quercetin-3-O-galactoside, quercitrin, and quercetin. Hyperoside and isoquercetin were reported to be the most significant contributors to the antioxidant capacity displayed by the methanolic extracts prepared from $H$. capitatum, quantified using the DPPH (IC $50,16.82 \pm 0.58 \mu \mathrm{g} \mathrm{mL}^{-1}$ ), ABTS $\left(\mathrm{IC}_{50}, 9.24 \pm 0.28 \mu \mathrm{g} \mathrm{mL}^{-1}\right.$ ), and $\beta$-carotene bleaching (IC $50,41.69 \pm 1.29 \mu \mathrm{g} \mathrm{mL}^{-1}$ ) methods. Eroglu Ozkan et al. (2018) obtained a higher antioxidant activity in crude methanolic extracts from $H$. neurocalycinum when compared to
H. malatyanum. These authors measured DPPH $\left(\mathrm{EC}_{50}, 0.251 \pm 0.01 \mathrm{mg}\right.$ $\left.\mathrm{mL}^{-1}\right)$, superoxide anion radical scavenging $\left(\mathrm{EC}_{50}, 0.613 \pm 0.05 \mathrm{mg}\right.$ $\mathrm{mL}^{-1}$ ), and inhibition of lipid peroxidation $\left(\mathrm{EC}_{50}, 2.49 \pm 0.09 \mathrm{mg}\right.$ $\mathrm{mL}^{-1}$ ). DPPH radical scavenging and metal-reducing ability were measured using FRAP and CUPRAC tests. The results showed that the hydroethanolic extract produced from the aerial parts of $H$. perfoliatum presented strong antioxidant capacities (Celep et al., 2017). Phenolic acids such as gallic, chlorogenic, caffeic, and p-coumaric were also linked to the radical-scavenging capacity of methanol and chloroform-methanolic extracts of $H$. perfoliatum (Del Monte et al., 2015).

Hyperforin is well-known for its anti-inflammatory, anti-tumour, anti-bacterial, and antioxidant properties. Haag et al. (2014) reported the application of a hyperforin-rich formulation to strengthen the skin barrier function. Eleven healthy volunteers (six females, five males, aged 21-42) were included in this study. After application, VIS/NIR-induced radical formation was inhibited up to $45 \%$. Furthermore, the skin lipid profile was investigated, applying HPTLC on skin lipid extracts. The lipid profile was found to increase directly after a single cream application; only for ceramide and squalene the improvement was significant, no relevant increase was observed for cholesterol. These results indicate that regular use of the hyperforin-rich cream can reduce the radical formation and help stabilize skin lipids, which are responsible for maintaining the skin barrier function. Similarly, the radical scavenging effect of a formulation containing $H$. perforatum extract rich in hyperforin, in a double-blind placebo-controlled study, was carried out in 11 healthy volunteers by Arndt et al. (2013). The results showed that radical formation could be reduced by almost $80 \%$ when applying the hyperforin-rich cream onto the skin. A formulation containing $44.3 \%$ hyperforin and free of hypericin was investigated for its in vivo photoprotective and radical protection capacity (Meinke et al., 2012). Assays were also conducted in vitro in HaCaT keratinocytes irradiated with solar simulated radiation, and the results showed that hyperforin $\left(^{E C_{50}}\right.$, $0.42 \mu \mathrm{g} \mathrm{mL}^{-1}$ ) was much more effective when compared to trolox $\left(\mathrm{EC}_{50}\right.$, $12 \mu \mathrm{g} \mathrm{mL}^{-1}$ ). The radical protection factor of the formulation was found to present very high radical scavenging activity $\left(200 \times 10^{14}\right.$ radicals $\mathrm{mg}^{-1}$ ). Furthermore, UV erythema test was conducted in twenty-two healthy volunteers ( 4 men and 18 women, aged between 19 and 59 years) and the formulation was found to significantly reduced UVB-induced erythema as opposed to the placebo group. These results show that hyperforin is a powerful free radical scavenger and can be utilised to suppress the severity of an ageing skin.

To the authors' best knowledge, when compared to other biological cosmeceutical assays, the antioxidant capacity remains the most widely reported among Hypericum species.

\subsection{Anti-ageing activity}

Collagen fibres are the principal structural component of the dermis, giving the skin its tensile strength; while elastin fibres contribute to its elasticity and resilience (Tobin, 2016). Skin ageing is a process caused by intrinsic and extrinsic ageing factors, both responsible for moderate to drastic changes in skin structure and elasticity. Intrinsic skin ageing represents the "normal" course of ageing of all tissues, strongly associated with chronological age, genetic influence, and internal factors, such as hormones and metabolic substances. In contrast, the extrinsic skin ageing process is the result of exogenous factors: sun exposure (photoaging), environmental toxins, infectious agents, and miscellaneous lifestyle components (i.e. smoking and diet) (Chiocchio et al., 2018; Tobin, 2016).

Histologically, chronologically aged skin exhibits general atrophy of the extracellular matrix (ECM) reflected by a decreased in fibroblasts number and reduced levels of collagen and elastin. The latter is thought to result from both a reduction in protein synthesis affecting mainly types I and III of collagen in the dermis and an increased breakdown of extracellular matrix proteins (Rittié and Fisher, 2002). Conversely, 
photoaged skin is described as exhibiting an increased epidermal thickness and alterations in tissue organisation; being possible to observe the accumulation of amorphous elastin-containing material that resides beneath the epidermal-dermal junction (Rittié and Fisher, 2002).

Oxidative stress is thought to play a central role in initiating and driving the signalling events that lead to the cellular response following UVR exposure. UV irradiation increases the formation of reactive oxygen species (ROS) and decreases in the skin's own antioxidant enzymes pool. UV activation of growth factor or cytokine receptors leads to the activation of extracellular signal-regulated kinase (ERK), c-Jun N-terminal kinases (JNK), and p38 mitogen-activated protein kinases. This activation is enhanced by a joint production of ROS, which can increase growth factor receptors inhibiting protein tyrosine phosphatases (PTPs) and/or directly activating mitogen-activated protein kinase kinases (MKKKs). Once activated by MKKKs, mitogen-activated protein kinases (MAPKs) can then phosphorylate transcription factors (e.g. Elk-1, c-Jun, ATF-2) leading to an increased expression of the transcription factor activator protein 1 (AP-1), which results in both upregulation of matrix metalloproteinases (MMPs) and down-regulation of procollagen I production (Rittié and Fisher, 2002). Similarly to photoaging, during the chronological ageing process, increased ROS production alters gene and protein structure and function, leading to skin damage, caused by the activation of several downstream protein cascades (Chiocchio et al., 2018; Rittié and Fisher, 2002; Tobin, 2016).

Although collagen and elastin are the major proteins present in the ECM; hyaluronic acid (HA) is also an essential component. HA can hold moisture to the skin, contributing its mechanical resistance and flexibility (Boran, 2018). Collagenase, elastase, and hyaluronidase are ECM degrading enzymes resultant from reactive species activation through different proteins cascades; these enzymes activity compromise skin structural integrity, culminating in both photo and chronological skin ageing signs. Due to their well-reported anti-collagenase, anti-elastase, and anti-hyaluronidase activities, Hypericum species represent a largely unexplored source of bioactive molecules that can be utilised to develop cosmetic formulations exhibiting antiaging properties (Table 1). As shown in Table 1, collagenase and elastase inhibitory activities have been reported for several Hypericum species, including H. androsaemum, $H$. ascyron, $H$. calycinum, $H$. confertum, $H$. hircinum L., H. origanifolium, and H. perforatum (Antognoni et al., 2017; Boran, 2018; Ersoy et al., 2019; Li et al., 2019a,b; Mandrone et al., 2015). To the best of the authors' knowledge, only Ersoy et al. (2019) reported anti-hyaluronidase activity for three Hypericum species, namely $H$. perforatum, $H$. calycinum, and $H$. confertum. All the plants' methanolic extracts presented strong hyaluronidase inhibitory capacities. The majority of the findings mentioned above identified polyprenylated acylphloroglucinols and phenolic compounds as being the most important contributors to the Hypericum species skin ageing enzymes inhibition proprieties. Regarding isolated compounds, Li et al. (2019a,b) identified 8 polyprenylated acylphloroglucinols through detailed spectroscopic data analysis from dried flowers of $H$. ascyron. The isolated compounds were identified as ascyronone $\mathrm{E}$, ascyronone $\mathrm{F}$, ascyronone $\mathrm{G}$, hypelodin $\mathrm{B}$, hypercohin $\mathrm{K}$, furohyperforin, hypercohin $\mathrm{G}$, and hyphenrone. All the molecules revealed significant dose-dependent inhibition against elastase enzymes, with ascyronone $\mathrm{E}(4.3 \pm 0.4 \mu \mathrm{M})$ and furohyperforin $(2.4 \pm 0.3 \mu \mathrm{M})$ being the most potent. High levels of ROS are known to enhance MMPs production and consequent collagen and elastin degradation. Hence, their inhibition may play a vital role in suppressing both chronological and UV induced skin ageing signs. Regarding Hypericum species, only $H$. formosanum and $H$. olympicum have been reported to suppress the expression of MMP-1 and MMP-9, respectively, upon exposure to UV radiation (Huang and Liaw, 2017; Kurt-celep et al., 2020). The numerous findings published up-to-the-date showed that most Hypericum plants are an essential source of biomolecules that can be utilised as additives in cosmetic formulations to suppress ageing signs. However, a detailed understanding of the mechanism of action behind their reported anti-ageing properties is essential to help bridge this gap.

\subsection{Anti-tyrosinase activity}

Skin pigmentation is the consequence of the melanin synthesis in melanocytes. Tyrosinase is the rate-limiting enzyme during melanin pathway biosynthesis, catalysing three different reactions that lead to the formation of eumelanin (brown-black pigment) and pheomelanin (yellow, red pigment) (Taofiq et al., 2016a). The enhanced activity of the intermediate tyrosinase enzyme is caused by long term exposure to UV radiation, auto-immune conditions, hormonal changes (causing the release of $\alpha$-melanocyte-stimulating hormone), and genetic factors. There are several signal transduction pathways responsible for increasing melanin production through the regulation of mRNA expression of tyrosinase and tyrosinase-related proteins (TRP1 and TRP2). Melanin biosynthesis is initiated by the microphthalmia-associated transcription factor (MITF), which binds to the promoter region of TRP-1 and TRP-2, causing an increase in enzyme expression (Huang et al., 2014; Pillaiyar et al., 2017). Hence, there is an increased need to discover melanogenesis inhibitors that target various signalling steps in the melanin biosynthesis pathways, either directly or indirectly. Hyperpigmentation is a skin condition resulting from a continuous melanin synthesis, characterised by dark and brown spots, and irregular grey patches on the face, neck, and trunk. Compounds such as hydroquinone, retinoic acid, and corticosteroids, are the most widely utilised to treat hyperpigmentation disorders. However, there are many safety concerns regarding their application on the skin, namely their potential to be carcinogenic, cause contact dermatitis, post-inflammatory hypopigmentation, exogenous ochronosis, cell irritation, and exudation of offensive fish odour from the skin (Chaowattanapanit et al., 2017). These adverse effects have resulted in the withdrawal of some of these components from the European market (EU Cosmetic Regulation 1223/2009). In contrast, some Asian markets still allow the use of hydroquinone at lower and presumably safer concentrations (Japanese Pharmaceutical Law in 2001) (Ando et al., 2010). These concerns have motivated the search for novel ingredients from natural sources with the capacity to inhibit one or more steps in the melanin biosynthetic pathway, which exhibit a safer profile. The use of plant extracts and their derived phytochemicals have shown promising potential and have been identified as future hyperpigmentation correcting ingredients (Mukherjee et al., 2018; Silva et al., 2020). Species belonging to the Hypericum genus have shown strong tyrosinase inhibition capacity (Table 1). Extracts prepared from $H$. androsaemum, H. calycinum, H. Confertum, H. lanuginosum, H. Perforatum, and $H$. salsugineum have all been reported to show tyrosinase inhibitory capacities, with their results either expressed in terms of $\mathrm{EC}_{50}$ values or kojic acid equivalent (Altun et al., 2013; Bender et al., 2018; Ersoy et al., 2019; López et al., 2016; Mahomoodally et al., 2019). The tyrosinase inhibitory properties of most biomolecules are scientifically validated using Kojic acid as a positive control. This fungal metabolite is currently used as a cosmetic skin-whitening agent, which displays a competitive mode of tyrosinase inhibition. To the author's best knowledge, only the methanolic extracts prepared from the non-flower shoots (NFS) and flower shoots (FS) of $H$. perforatum displayed tyrosinase inhibitory potential that is comparable to kojic acid. The NFS and FS extracts inhibited tyrosinase enzyme by $90 \%$ and $87 \%$, respectively, compared to $97 \%$ reported for kojic acid (Tusevski et al., 2018). The methanolic extracts of $H$. olympicum, $H$. pruinatum, and $H$. scabrum were reported to present excellent tyrosinase inhibition (Llorent-Martínez et al., 2018). The most abundant compounds in those extracts were quercitrin, hyperoside, myricitrin, chlorogenic acid, and neo-chlorogenic acid. All the above compounds were selected for molecular docking simulation by the authors. In all cases, the binding pocket and the docking scores revealed that chlorogenic acid was the best inhibitor of tyrosinase among the tested compounds. Mahomoodally et al. (2019) also identified chlorogenic acid in $H$. lanuginosum extracts as the compound 
Table 1

Biological properties of different Hypericum species extracts and their isolated metabolites.

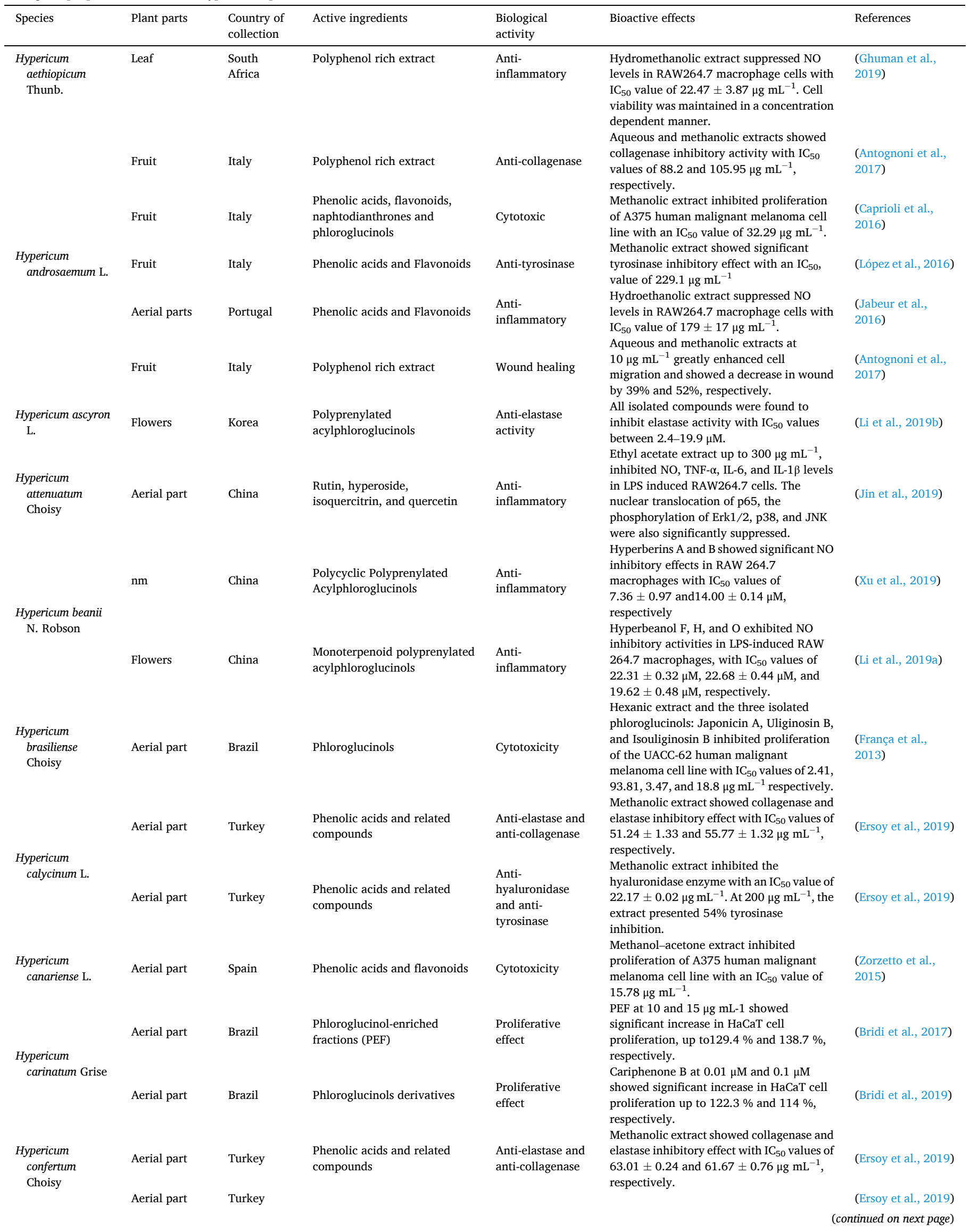


Table 1 (continued)

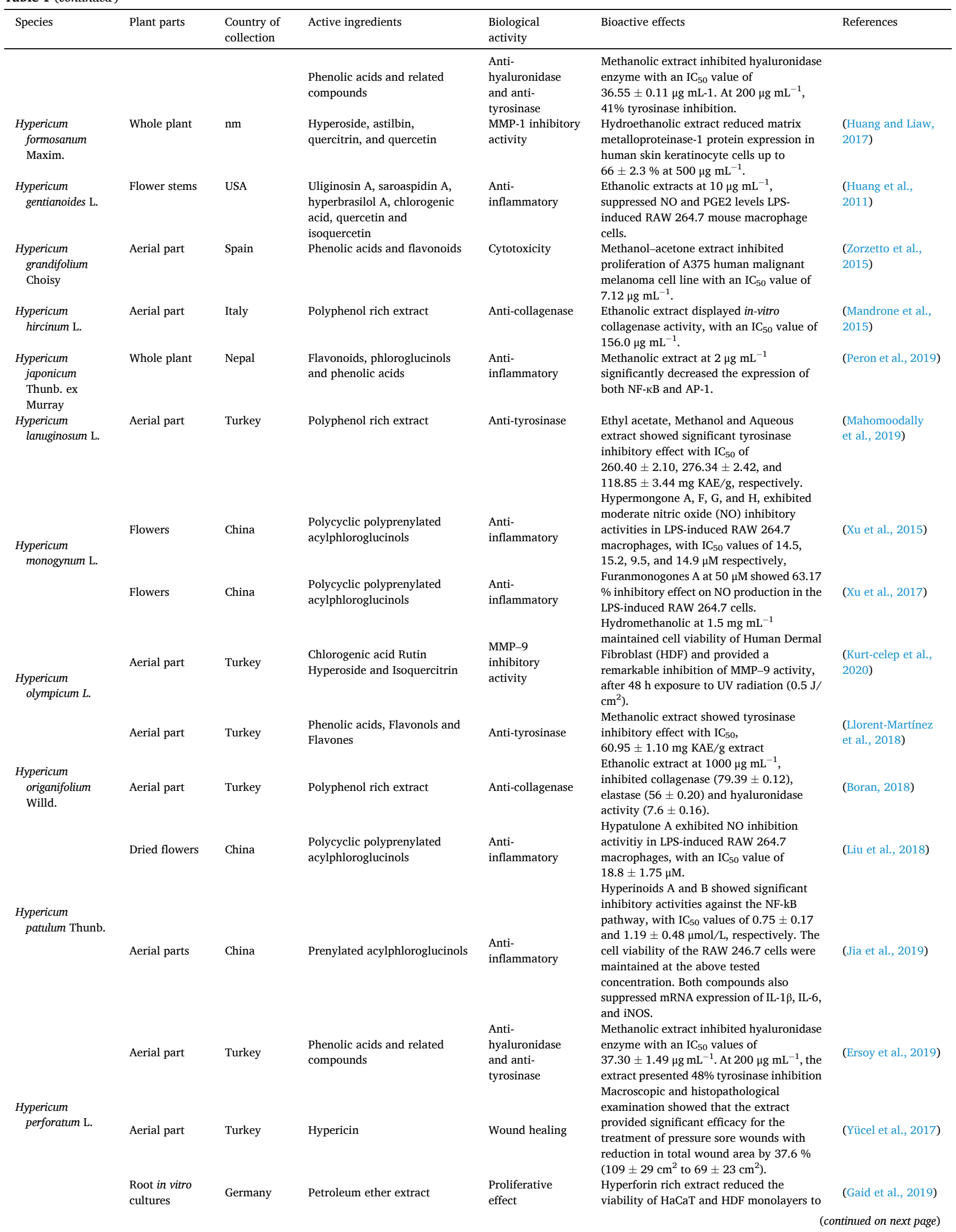


Table 1 (continued)

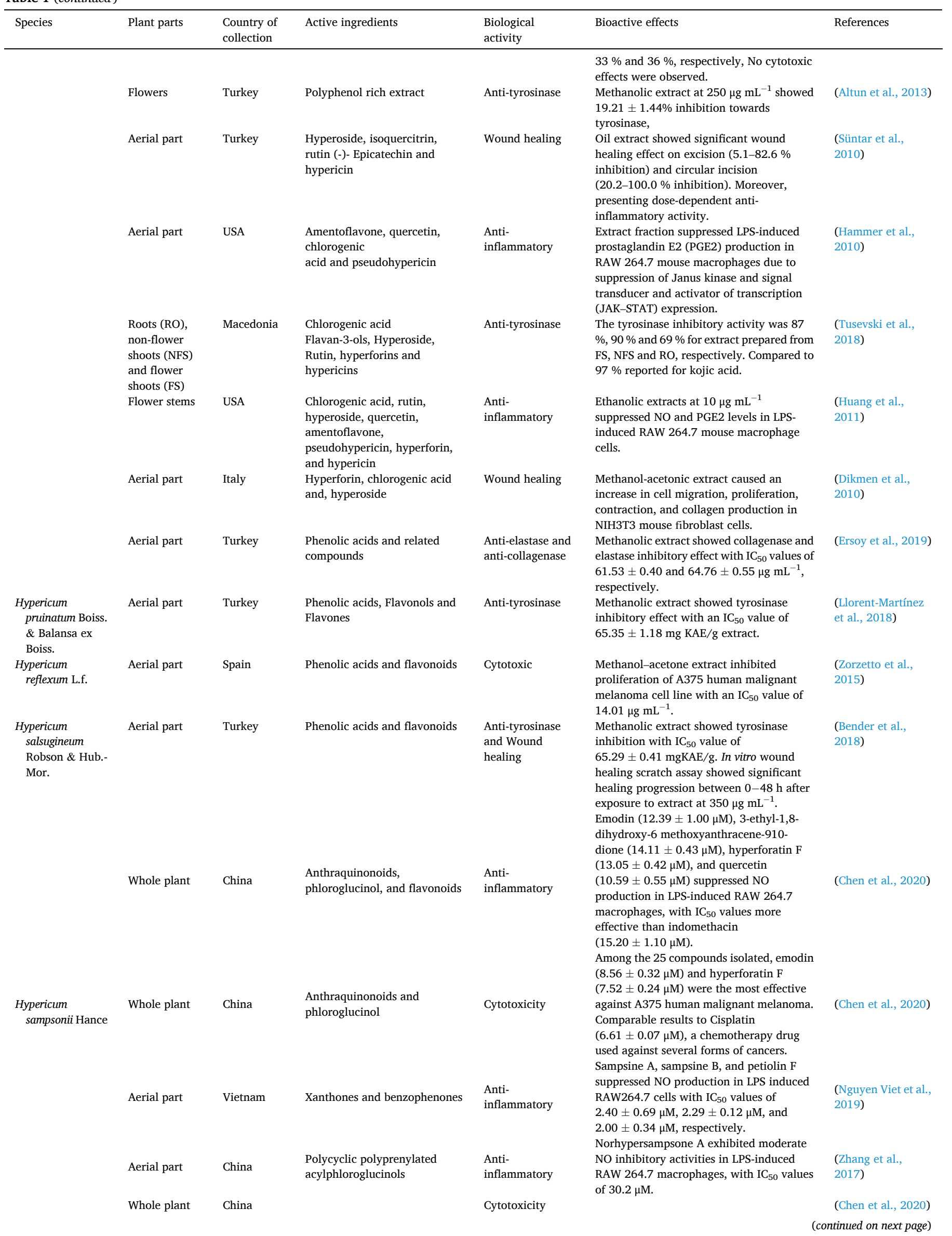


Table 1 (continued)

\begin{tabular}{|c|c|c|c|c|c|c|}
\hline Species & Plant parts & $\begin{array}{l}\text { Country of } \\
\text { collection }\end{array}$ & Active ingredients & $\begin{array}{l}\text { Biological } \\
\text { activity }\end{array}$ & Bioactive effects & References \\
\hline & & & $\begin{array}{l}\text { Anthraquinonoids, xanthones, } \\
\text { benzophenone, phloroglucinol, } \\
\text { flavonoids, sterol, and alkaloid }\end{array}$ & & $\begin{array}{l}\text { Ethanolic extract inhibited proliferation of } \\
\text { A375 human malignant melanoma cell line, } \\
\text { with an } \mathrm{IC}_{50} \text { value of } 52.35 \pm 0.17 \mu \mathrm{g} \\
\mathrm{mL}^{-1} \text {. }\end{array}$ & \\
\hline & Whole plant & China & $\begin{array}{l}\text { Anthraquinonoids, xanthones, } \\
\text { benzophenone, phloroglucinol, } \\
\text { flavonoids, sterol, and alkaloid }\end{array}$ & $\begin{array}{l}\text { Anti- } \\
\text { inflammatory }\end{array}$ & $\begin{array}{l}\text { Ethanolic extracts at } 32.44 \pm 1.21 \mu \mathrm{g} \mathrm{mL}^{-1} \\
\text { suppressed NO levels in LPS-induced RAW } \\
264.7 \text { mouse macrophage cells. }\end{array}$ & (Chen et al., 2020) \\
\hline $\begin{array}{l}\text { Hypericum } \\
\text { scabroides } \\
\text { Robson \& } \\
\text { Poulter }\end{array}$ & Aerial part & Turkey & $\begin{array}{l}\text { Pseudohypericin, hypericin, } \\
\text { chlorogenic acid, rutin and } \\
\text { hyperoside }\end{array}$ & $\begin{array}{l}\text { Anti- } \\
\text { inflammatory }\end{array}$ & $\begin{array}{l}\text { Methanolic extract showed decrease in } \\
\text { mouse-paw volume by } 78.0 \% \text { and } 40.44 \% \\
\text { after } 1 \mathrm{~h} \text { and } 3 \mathrm{~h} \text { in vivo exposure, } \\
\text { respectively. }\end{array}$ & $\begin{array}{l}\text { (Mansour et al., } \\
\text { 2014) }\end{array}$ \\
\hline \multirow[b]{2}{*}{$\begin{array}{l}\text { Hypericum } \\
\text { scabrum L. }\end{array}$} & Aerial part & Turkey & $\begin{array}{l}\text { Phenolic acids, Flavonols and } \\
\text { Flavones }\end{array}$ & Anti-tyrosinase & $\begin{array}{l}\text { Methanolic extract showed tyrosinase } \\
\text { inhibitory effect, with } \mathrm{IC}_{50} \text { of } \\
65.35 \pm 1.18 \mathrm{mg} \mathrm{KAE} / \mathrm{g} \text { extract. }\end{array}$ & $\begin{array}{l}\text { (Llorent-Martínez } \\
\text { et al., 2018) }\end{array}$ \\
\hline & Aerial part & $\mathrm{nm}$ & $\begin{array}{l}\text { Polycyclic polyprenylated } \\
\text { acylphloroglucinols }\end{array}$ & Wound healing & $\begin{array}{l}\text { Hypermongone C cause significant } \\
\text { migration of HDFs cells at } 0.1 \text { and } 1 \mu \mathrm{g} \mathrm{mL}- \\
1 \text { over } 18 \text {-h incubation. Cell viability was } \\
\text { also maintained at the above tested } \\
\text { concentrations. }\end{array}$ & $\begin{array}{l}\text { (Moghadam et al., } \\
\text { 2019) }\end{array}$ \\
\hline
\end{tabular}

nm- not mentioned.

presenting the best docking pose against the tyrosinase enzyme. Ample evidence has suggested that most Hypericum species are important sources of biomolecules with interesting tyrosinase inhibitory capacities. Still, findings on the contribution of their isolated compounds have not been well exploited. A significant number of the findings on tyrosinase inhibitors have been conducted using commercial tyrosinase enzyme obtained from the Agaricus bisporus L, one of the most widely cultivated edible mushroom. Nonetheless, some evidence has shown that there are some differences in the inhibition potential of compounds against fungal and human tyrosinase, due to their different active site oxidative states, substrate specificity, and amino acid sequence (Mann et al., 2018; Mukherjee et al., 2018). Hence, further findings should be conducted using human tyrosinase to find novel and effective tyrosinase inhibition molecules from Hypericum species.

\subsection{Anti-inflammatory activity}

Inflammation is a protective mechanism to remove harmful stimuli from the body. The use of anti-inflammatory molecules has been employed as an effective treatment to suppress its severity, which is often associated with pathogenesis (Taofiq et al., 2016b). In this context, bioactive extracts and their compounds are employed worldwide in folk medicine to suppress the severity of inflammatory processes, including skin inflammations. Hence, there is a continuous search for biomolecules with the potential to inhibit the expression of inflammatory mediators such as nitric oxide (NO), interleukins (IL 1 $\beta$, IL-6, IL-8), tumour necrosis factor (TNF- $\alpha$ ), and prostaglandin E2 (PGE2). The Nuclear Factor kappa-light-chain-enhancer of activated B cells (NF- $\mathrm{KB}$ ) is a transcription factor that regulates the expression of several inflammatory mediators, which play vital roles in the inflammation process. Recent findings have identified natural biomolecules as inhibitors of specific steps in the pathway leading to NF-кB release (Chen et al., 2016; Zhang et al., 2014). In the continuous search for new bioactive molecules against inflammation, some Hypericum species are increasingly being referred to as rich sources of such components, especially those belonging to the phloroglucinols class (hyperberins, hyperbeanol, hypermongone, and furanmonogones) (Li et al., 2019a,b; Xu et al., 2019, 2017, 2015). Some Hypericum compounds were pointed as both suppressors of inflammatory mediators and inhibitors of some specific pro-inflammatory enzymes. Concerning the anti-inflammatory potential of biomolecules from Hypericum species shown in Table 1, most research findings were undertaken to quantify the suppression of different inflammatory mediators (interleukins, TNF- $\alpha$, and NO) in a mouse macrophage cell model (RAW 264.7). Other studies utilised different test models such as the carrageenan-induced paw oedema in rodents (Mansour et al., 2014). To the author's best knowledge, no findings on the anti-inflammatory capacity of extracts from Hypericum species or their compounds have been reported against cyclooxygenase (COX) enzymes. These enzymes catalyse the rate-limiting step in the biosynthesis of prostaglandins, prostacyclins, and thromboxanes from arachidonic acid. There are two major isoforms of the cyclooxygenase enzyme: COX-1 forms prostaglandins that perform housekeeping functions and COX-2 forms prostaglandins that are involved in inflammation. Prostaglandins play a significant role in several biological processes, including gastric mucosal protection, thermoregulation, platelet aggregation, control of renal blood flow and kidney function (Elgorashi and McGaw, 2019; Taofiq et al., 2016b). Contrasting, other prostaglandins have been associated with pathological functions such as pain, fever, arthritis, asthma, and inflammatory bowel disease. Prostaglandin E2 (PGE2) is mainly associated with the pathogenesis of different inflammatory diseases. Huang et al. (2011) and Hammer et al. (2010) were the only authors reporting Hypericum potential to reduce PGE2 levels: $H$. gentianoides flower and stem ethanolic extract at $10 \mu \mathrm{g}$ $\mathrm{mL}^{-1}$ and $H$. japonicum whole plant methanolic extract at $2 \mu \mathrm{g} \mathrm{mL}^{-1}$, respectively. Mitogen-activated protein kinase (MAPKs) play crucial roles in inflammation induction. These family of protein kinases can be activated through the phosphorylation of several protein kinases, including Erk1/2, p38, and JNK. The mechanism behind the anti-inflammatory capacity of most natural biomolecules has been associated with the inhibition of the phosphorylation of the above-mentioned protein kinases. $H$. attenuatum ethyl acetate prepared using ultrasound-assisted extraction at $300 \mu \mathrm{g} \mathrm{mL} \mathrm{m}^{-1}$, suppressed the expression of the pro-inflammatory cytokines TNF- $\alpha$, IL- 6 , and IL-1 $\beta$. The effect of the extract on the NF- $\mathrm{KB}$ and MAPK signalling pathways were also investigated using immunofluorescence assays. The polyphenol-rich extract was found to prevent the nuclear translocation of p65 and suppress the phosphorylation of Erk1/2, p38 and JNK. To the author's best knowledge, only Peron et al. (2019) reported the in vitro inhibition of NF- $\mathrm{kB}$ using extracts from Hypericum species. Regarding isolated compounds, two polycyclic meroterpenoids (Hyperinoids A and B) from $H$. patulum were reported to significantly inhibit NF- $\mathrm{KB}$ and downregulated the expression of IL-1 $\beta$, IL-6, and iNOS (Jia et al., 2019). Isolated compounds from the polyprenylated acylphloroglucinols class were the most important contributors to the anti-inflammatory capacity of most Hypericum species, which have been largely associated with suppression of inflammatory mediators expression. Some of those isolated compounds are Hyperberins A and B, Hyperbeanol F, H, and O, all isolated from H. beanie (Li et al., 2019a,b; Xu et al., 2019); 
Hypermongone A, F, G, and H, and Furanmonogones A, isolated from the flowers of H. monogynum (Xu et al., 2017, 2015); Hypatulone A, isolated from $H$. patulum (Liu et al., 2018); and Norhypersampsone A, isolated from H. sampsonii (Zhang et al., 2017). Biomolecules belonging to other classes such as anthraquinonoids, xanthones, benzophenones, phenolic acids, and flavonoids, have also been identified as contributors to the anti-inflammatory activity of Hypericum species (Chen et al., 2020; Jabeur et al., 2016; Nguyen Viet et al., 2019). A detailed anti-inflammatory overview was reported for hyperoside, a flavonol glycoside mainly found in plants of the genera Hypericum and Crataegus. Hyperoside at $10 \mu \mathrm{mol} \mathrm{L}^{-1}$ maintained the viability of fibroblast-like cells, but a concentration-increased-treatment $\left(100 \mu \mathrm{mol} \mathrm{L}^{-1}\right)$ reduced the cell viability by $27 \%$. The compound suppressed the production of TNF $\alpha$, IL-6, and IL- $1 \beta$ in a concentration-dependent manner, while also suppressing nuclear translocation and phosphorylation of p65, and

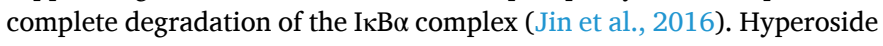
isolated from $H$. perforatum also reduce cytokine production, iNOS expression, and inhibited the activation of NF- $\mathrm{BB}$ by blocking Rel/p65 translocation to the nucleus (Kim et al., 2011). Despite the interesting anti-inflammatory properties reported for these isolated compounds, their mechanism of action was not fully unveiled. The use of computational docking tools to simulate the affinity of these compounds can be further utilised to examine how they bind to the active sites of enzymes involved in the inflammation process. Najafizadeh et al. (2012) investigated the anti-psoriasis effects of a topical ointment containing extract of $H$. perforatum (5\%). Ten patients (four men and six women aged between 20 and 55 years with mild plaque psoriasis) were selected and treated with $H$. perforatum ointment. The ointment was applied to each patient twice daily for 4 weeks, and the mean erythema scores (MRA), scaling scores (SC) and thickness scores (TC) before and after treatment were the evaluated parameters. The results showed that the modified Psoriasis Area Severity Index (PASI) ratings were significantly lowered. Additionally, MRA, SC TC were also significantly reduced from 2.6, 2.5, 2.4 to $1.1,0.7,1.1$, respectively. An ointment formulated with the extract of $H$. perforatum ( $5 \% \mathrm{wt} / \mathrm{wt}$ ), vaseline ( $84 \% \mathrm{wt} / \mathrm{wt}$ ), propylene glycol (10\% wt/wt), and avicel (1\% wt/wt) was reported by Mansouri et al. (2017) to suppress the severity of psoriasis. A double-blind, a placebo-controlled, and a pilot study were carried out in patients with mild to moderate plaque-type psoriasis. PASI scores, histological, and clinical changes were investigated after topical application of the ointment. The results showed a reduction in erythema, scaling, and thickness when compared to the placebo group. Similarly, clinical and histological features of treated lesions were improved.

\subsection{Wound healing activity}

Wound healing involves a series of complex biological processes that are controlled by different cell types such as the macrophages, dermal fibroblasts, epidermal keratinocytes, and the endothelial cells integrated in a well-orchestrated manner to repair the damaged skin. In general, the wound healing process comprises different overlapping steps such as inflammation, which is associated with the migration of immune cells to the wound area to prevent pathogen invasion, haemostasis, or blood clotting. Together with the proliferation and migration of fibroblasts, the development of new blood vessels (angiogenesis), and tissue reepithelialisation (Moghadam et al., 2019). Wound treatment involves the use of topical antimicrobial and anti-inflammatory agents or a combination of both. Despite their widespread use, these drugs are associated with unwanted side effects and loss of therapeutic response, mainly antibiotic resistance. Hence, it is essential to find alternative ingredients with fewer side effects and active wound healing properties. Natural biomolecules have demonstrated wound healing properties mainly due to their potential to target multiple signalling pathways and effectively enhance fibroblast proliferation and migration, angiogenesis promotion, and suppression of inflammatory mediators overproduction (Beißner et al., 2018; Marrelli et al., 2019; Montoya et al., 2015). Extracts from
$H$. androsaemum, $H$. perforatum, $H$. salsugineum, and $H$. scabrum have shown strong wound healing properties due to the structural diversity of their active ingredients, which synergistically interact to provide an overall healing effect (Antognoni et al., 2017; Bender et al., 2018; Dikmen et al., 2010; Moghadam et al., 2019; Yücel et al., 2017). The wound healing activity of most Hypericum species, as shown in Table 1, have been associated with the stimulation of fibroblast migration, collagen production, suppression of inflammation, efficiently contributing to the wound closure of the damaged area and its reepithelialisation (Bridi et al., 2017; Moghadam et al., 2019; Süntar et al., 2011). The species exhibiting wound healing properties presented different levels of impact on the angiogenesis, inflammation, collagen production, fibroblast migration, and reepithelization parameters. Therefore, the combination of different extracts can assure a more efficient and stable response towards healing. Regarding isolated compounds, only Moghadam et al. (2019) studied the potential of hypermongone C, a polycyclic polyprenylated acylphloroglucinol (PPAP), to accelerate wound healing through fibroblast migration, promotion of angiogenesis, and the suppression of pro-inflammatory cytokines release. Hypermongone $\mathrm{C}$ $\left(10 \mu \mathrm{g} \mathrm{mL}^{-1}\right) 24 \mathrm{~h}$ exposure maintained HDF cell viability up to $65 \%$. At the nontoxic concentrations, the compound induced migration of HDF cells towards the cell-free gap, revealing a remarkable $80 \%$ closure when compared to the $45 \%$ obtained by the control (untreated cells). Cell viability and cytotoxicity assays were performed to evaluate hyperforin concentrations presenting fewer toxic effects and; therefore, safer for topical application (Füller and Müller-Goymann, 2018). Hyperforin concentrations ranging from 0.05 to $1 \mu \mathrm{M}$ did not reduce the viability of $\mathrm{HDF}$; whereas, at $10 \mu \mathrm{M}$, the cell viability was suppressed by $75 \%$. Additionally, after a $24 \mathrm{~h}$ exposure, there was no increase in HDF cells caspase activity, which demonstrates that hyperforin did not induce apoptosis of these cell line. The authors couldn't demonstrate the wound healing potential of isolated hyperforin, which suggests that the wound healing effect of Hypericum extracts might be associated with the synergistic effect of their different constituents. Giudice et al. also confirmed the wound healing activity of a phytocosmetic formulations prepared from the aerial parts of $H$. perforatum either alone or in combination with other plant-derived bioactive components (Giudice et al., 2017). The authors reported a significant improvement in horses skin lesions of different breeds, age, and attitude. This healing capacity was attributed to the antibacterial, antioxidant, and anti-inflammatory properties of the ointment. $H$. perforatum gel also exerted significant positive effects $(p<0.05)$ in the wound healing of Wistar rats, when compared to the placebo group (Castro et al., 2012). The improvements were associated with tissue reepithelialisation, the formation of new blood vessels, and an increase in collagen fibres levels. Interesting findings for an $H$. perforatum ointment against linear incisions, circular excisions, and thermal burns were reported by Irina Prisăcaru et al. (2013). The authors described a significant improvement in wound contraction rate and a faster period of reepithelialisation. Most findings have identified that bioactive molecules, extracts, and formulations of some Hypericum species play crucial roles in the management of chronic and infected wounds. However, the mechanism behind these properties remains poorly understood. Due to their lengthy historical application against inflammatory disorders, and their wound healing capacity, widely reported in Turkish medicine, a novel ointment formulation was developed. Süntar et al. (2011) utilised extracts from H. perforatum, Origanum majorana L., Origanum minutiflorum Schwrd., and Salvia triloba L. The authors reported its wound capacity both in linear and circular incision wound models. The topical application of the ointment onto the incised wounds demonstrated the best injury tensile strengths, up to $33.3 \%$ on day 10 , while the wound contractions were respectively 45.9 $\%, 74.8 \%$, and $91.8 \%$ on days 8,10 , and 12 . The final formulation was not able to reduce elastase activity in vitro, but it displayed anti-collagenase activity in a concentration-dependent manner with an $\mathrm{IC}_{50}$ value of $7.4 \pm 1.1 \mathrm{mg} \mathrm{mL}^{-1}$.

Recent findings have involved the development of active wound 
dressing materials, capable of protecting the wound from microorganism and ensure effective closure. There are various pathways for their development, mainly requiring incorporation of bioactive molecules into wound dressing materials such as collagen, alginate, hyaluronic acid, chitosan, fucoidan, and Poly- $N$-acetyl glucosamine; thereby, ensuring their controlled release (Güneş and Tihmınlıoglu, 2017). This strategy is a practical approach to control inflammation, prevent infections, as well as promote tissue regeneration. In the last few years, different nano and microparticulate formulations have been designed in the form of spheres and capsules. Various polymeric matrices (solid and liquid lipids) were used to encapsulate bioactive molecules for medical, cosmetic, and pharmaceutical applications (Battaglia and Ugazio, 2019; Vieira et al., 2020). These particles are dynamic and versatile delivery tools, offering advantages such as high kinetic stability, rigid morphology, high loading capacity, and high encapsulation efficiency. Concerning lipid-based nanoparticles, their production costs are low, with biodegradable materials that are of GRAS status (generally recognised as safe); thereby, enhancing their potential large-scale industrial production without the use of organic solvents (Souto et al., 2020a, 2020b).

Nanotechnology has played a role in promoting the wound healing process. The encapsulated bioactive ingredients and some of the polymeric materials exhibit potent antimicrobial, anti-inflammatory, and pro-angiogenic properties (Naderi et al., 2018). Hypericin is a potent photosensitiser identified in most Hypericum species. However, due to its lipophilic properties, its utilisation in therapeutic applications is limited. Accordingly, Nafee et al. (2013) developed a biodegradable nanocarrier for hypericin using Polyethyleneglycol (PEG) and Polycaprolactone (PCL) copolymers, using a nanoprecipitation method in the absence of an emulsifier. The produced nanoparticles exhibiting uniform monomodal size distribution were found to inhibit MRSA. In vivo wound healing assays on Wistar rats revealed faster healing, with a significant reduction in wound diameter $(\sim 80 \%)$ after 10 days, better epithelialization, keratinization, and the development of collagen fibres. $H$. perforatum oil, at different concentrations $(0.25-1.5 \% \mathrm{v} / \mathrm{v})$, was incorporated into chitosan films produced by solvent casting method as a potential wound dressing material. The Chitosan-based films presented no cytotoxic effects in NIH3T3 fibroblast cells, enhancing their proliferation (Güneş and Tihmınlıoğlu, 2017). The results also showed that the chitosan films inhibited the growth of Escherichia coli and Staphylococcus aureus, making it a potential biomaterial for wound healing applications. Recently, Eğri et al. (2020) reported a better wound healing property for capsules with $H$. perforatum oil core formed by electrospinning PEG and PCL. The cell viability of the capsules in L929 mouse fibroblast cells was maintained, which is an indication of the biocompatibility and safety of the membranes. The controlled release of the active ingredients occurred due to the dissolution of PEG capsules, causing a significant decrease in the wound in vivo. Additionally, the expressions of collagen type I and III proteins were increased in comparison with the placebo group. Histopathologically, a shortened healing period was also observed. Liposomal encapsulation of hypericin was also mentioned as being a promising solution for antimicrobial photodynamic therapy, a new therapeutic strategy to fight microbial resistance (Plenagl et al., 2018). MultiSal ${ }^{\mathrm{TM}}$ Skin Repair is a product from Salvona that utilises a "smart" encapsulation system to release multiple ingredients ( $H$. perforatum extract and other active principles) in a gradual and sustained manner. The supplied elements help in skin repair and skin rejuvenation. To the authors' best knowledge, this is the only commercial product with microencapsulated Hypericum ingredients in the market.

\subsection{Cytotoxicity and photodynamic therapy}

Long term exposure to UV radiation has been identified to be among the risk factors leading to skin cancer. UVR is involved in the initiation-promotion-progression steps of carcinogenesis, which is mediated through various cellular, biochemical, and molecular cascades (Ramasamy et al., 2017). The activation of these complex cascades of events favour tumour progression and invasion; therefore, there is an increasing need to find robust, multi-target, and multifunctional ingredients against UVR-induced skin cancers. Most findings to date are associated with in vitro investigations in cell culture models such as keratinocytes, melanocytes, and fibroblast (Marques and MacNeil, 2016). Some studies have identified extracts from Hypericum species (H. androsaemum, $H$. brasiliense, $H$. canariense, $H$. grandifolium, $H$. reflexum, and $H$. sampsonii) as being interesting bioactive compounds with potent cytotoxic properties, mainly against melanoma cells of human origin (A375 and UACC-62 human malignant melanoma cell lines) (Caprioli et al., 2016; Chen et al., 2020; França et al., 2013; Zorzetto et al., 2015). The investigated cytotoxic compounds are mostly phloroglucinols (hyperforatin $\mathrm{F}$, japonicin, uliginosin, and isouliginosin B) and anthraquinonoids (emodin). Photodynamic therapy (PDT) is a novel, non-invasive therapeutic strategy used to destruct various cells and tissues. It regarded as a topic of current interest, mainly in the area of dermato-oncology. The basic principle of the photodynamic therapy (PDT) involves the local or systemic application of a photosensitizer (PS), a light-sensitive substance which generates cytotoxic species. These include lethal levels of singlet oxygen and reactive oxygen species (ROS) upon irradiation, thereby leading to the destruction of cellular targets through direct cellular damage, vascular shutdown, and activation of an immune response against the targeted cells (Kim et al., 2018; Lima et al., 2013; Tampa et al., 2019). Sharma and Davids validated the efficacy of hypericin-mediated photodynamic-induced cell death (Sharma and Davids, 2012). The authors reported that the viability of both a human pigmented melanoma (UCT Mel-1) and an unpigmented melanoma (A375) cell line were suppressed after exposure to UVA (1 J $\left.\mathrm{cm}^{-2}\right)$ treated with hypericin $(3 \mu \mathrm{M})$. Kleemann et al. (2014) also reported similar findings; these authors established that light-induced hypericin resulted in the photo destruction of the mitochondria and the endoplasmic reticulum of both UCT Mel-1 and A375 melanoma cells by compromising their membrane integrity, cell shrinkage, and finally, apoptosis. Additionally, the proliferative capacity of keratinocytes and fibroblast cells were enhanced after exposure to the extracts or isolated compounds obtained from Hypericum species (Table 1). Following the successful application of nanocarriers in various fields, hypericin-loaded solid lipid nanoparticles (Hy-SLN) were prepared using the ultrasonication technique by Lima et al. (2013). The produced nanoparticles were found to exhibit high encapsulation efficiency ( $80 \%)$ and drug loading capacity $5.22 \%(\mathrm{w} / \mathrm{w})$. Photodynamic therapy against B16-F10 mouse melanoma cell line proved that the hypericin-loaded nanoparticles presented better efficiency and cytotoxic effect when compared to free hypericin. These findings have shown the interesting skin cancer treatment properties of these biomolecules, without significantly giving any cytotoxic effect.

The results mentioned above have shown the interesting skin cancer treatment properties of these biomolecules, with no significant cytotoxic effect (Bridi et al., 2019, 2017).

\subsection{Antimicrobial and preservative properties}

Preservatives are added to cosmetics to prevent microbiological contamination during manufacture, storage, but principally throughout the usage period (Herman, 2019). From raw ingredients to the final cosmetic products, microbial safety has become a critical issue to the cosmetic industry. According to the European Union (EU) legislation, the results of challenge tests across the entire production chain are mandatory elements of the individual Cosmetic Product Safety Report (Kočevar Glavač and Lunder, 2018). The most utilised strains in these tests are the well-recognised skin pathogens Pseudomonas aeruginosa, S. aureus, E. coli, Candida albicans, and Aspergillus brasiliensis. Although in the EU, only the regulated preservatives listed in Annex V (EC) can be used in cosmetics and personal care products; exposure to some of these 
substances can produce skin irritation and sensitisation (Juliano and Magrini, 2018). Moreover, some studies recognise them as potential endocrine disruptors (Kerdudo et al., 2016; Kizhedath et al., 2019; Nohynek et al., 2013). These concerns, along with the increasing consumer demand for natural ingredients guided cosmetic manufacturers into a continuous search for innovative and multifunctional natural biomolecules (Secchi et al., 2016). In the EU, the number of certified natural preservatives is minimal when compared to the list of the conventional officially permitted, eight versus fifty-seven (Kočevar Glavač and Lunder, 2018). The main reasons behind these numbers discrepancy for natural preservatives are the absence of broad-spectrum activity, poor efficacy at low concentrations, unpleasant odour/colour, poor compatibility with other ingredients, irritation or allergenic potential, and cost. Despite these limitations, there is also an opportunity for researchers and cosmetic manufacturers to combine different multifunctional ingredients at lower concentrations, conferring a synergetic preservative effect on the product. The self-preserving approach in cosmetics has emerged in recent years. This method replaces traditional preservatives with cosmetic ingredients presenting multifunctional properties, which are primarily used as bioactive constituents for their positive effects on the skin but can also significantly contribute to the total preservative function (Kerdudo et al., 2016; Kočevar Glavač and Lunder, 2018; Varvaresou et al., 2009). P-anisic acid (masking), ethanol (solvent), glyceryl caprylate (emollient and emulsifying), grapefruit seed extract (masking and perfuming), Lactobacillus ferment (skin conditioning), and levulinic acid (perfuming and skin conditioning) are some of the functional ingredients with preservative properties approved by the EU and available at the CosIng database (Kočevar Glavač and Lunder, 2018). Plant-derived compounds vary in structure and chemical composition and can inhibit the growth and activity of many microorganisms. Recent studies have shown that phytochemicals exert their antibacterial activity through different mechanisms, such as damage to the bacterial membrane; suppression of virulence factors; inhibition of enzymes and toxins activity; and suppression of bacterial biofilm formation (Barbieri et al., 2017; Takó et al., 2020). Hypericum species possess a complex spectrum of bioactive molecules, which have been utilised as cosmeceutical ingredients due to their anti-ageing, photoprotective, wound healing, anti-inflammatory, and anti-tyrosinase properties. Additionally to the above-mentioned bioactive properties, some Hypericum species and their metabolites; in particular phloroglucinols, anthraquinones, xanthones, and tannins have also been reported as exhibiting a broad-spectrum antimicrobial activity (Nogueira et al., 2013; Saddiqe et al., 2010). In this context, the structural diversity and multifunctional properties presented by Hypericum species, underline them as feasible alternatives to replace synthetic cosmetic preservatives and antimicrobial substances to treat different skin problems associated with microorganisms overgrowth. Among the Hypericum genus, potent antifungal molecules have been identified in chloroform and methanolic extracts of $H$. garciae Pierce. The extracts displayed activity against a panel of clinical Candida isolates (C. albicans, C. parapsilosis, C. lusitaniae, C. tropicalis, C. intermedia, and C. glabrata), exhibiting results comparable to the MIC values obtained for fluconazole, a medicine widely used to treat fungal infections (Tocci et al., 2018). While most antimicrobial screenings are performed against common skin pathogens such as Staphylococci species, $P$. aeruginosa, and C. albicans, skin dermatophytes like Trichophyton mentagrophytes and Microsporum canis have been overlooked. This lack of information has been associated with the challenges of culturing these microbes and their resistance phenomena (Aneke et al., 2018). The broad-spectrum anti-microbial properties of dichloromethane-methanol and aqueous extracts prepared from $H$. perforatum leaves were utilised against $S$. aureus, Methicillin-resistant $S$. aureus, $S$. epidermidis, $P$. aeruginosa, C. albicans, $P$. acnes, T. mentagrophytes, and $M$. canis to validate their properties as potential ingredients to treat common skin diseases such as ringworm infections and Acne vulgaris (Mabona et al., 2013). The extracts exhibited similar MICs to some of the most potent antibiotic and antifungal substances tested, Ciprofloxacin and amphotericin B, respectively. The ethanolic extract of Hypericum revolutum Vahl also presented a better MIC $\left(31.25 \mu \mathrm{g} \mathrm{mL}^{-1}\right)$ against $P$. acnes when compared to the result obtained for the antibiotic tetracycline $(56.26 \pm 10.12 \mu \mathrm{g}$ $\mathrm{mL}^{-1}$ ) (Blom van Staden et al., 2017). The MICs reported for the ethanol extract of $H$. lydium Boiss against $E$. coli and $S$. aureus standard strains were $>1024 \mu \mathrm{g} \mathrm{mL}^{-1}$ and $16 \mu \mathrm{g} \mathrm{mL}^{-1}$, respectively (Aygül and Şerbetçi, 2020). It is interesting to note that gram-positive bacteria, such as $S$. aureus and Streptococcus pyogenes, and gram-negative bacteria like E. coli and $P$. aeruginosa, can both be found at an early stage or when a wound infection is fully developed (Moeini et al., 2020). Therefore, the antimicrobial properties of specific active secondary metabolites present in some Hypericum species strengthen their potential as wound healing components.

Regarding isolated compounds, four dimeric Acylphloroglucinols isolated from the Hypericum japonicum whole plant, Hyperjaponicols $\mathrm{A}-\mathrm{D}$, displayed significant antibacterial activity, with MICs ranging from $0.8-3.4 \mu \mathrm{M}$ against $E$. coli and $S$. aureus. These results were comparable to cefotaxime sodium, a beta-lactam third-generation cephalosporin antibiotic (Li et al., 2018). Hypericum extracts may be more active than the isolated components due to possible synergistic effects (Nogueira et al., 2013).

The results above-compiled have shown that Hypericum species extracts and isolated compounds have potential to be used as antimicrobial and preservative agents due to their broad-spectrum antimicrobial activity, which includes fungal strains, and gram-positive and negative bacteria.

\section{Safety and toxicity assessment}

The safety of extracts can be compromised due to the presence of one or more biomolecules. Therefore, knowledge of the molecules toxicology present in the extract plays a pivotal role in establishing their safety. Most experimental studies conducted concerning the safety of extracts or isolated compounds obtained from Hypericum species are related to cell viability determination after exposure. Studies using different cell cultures of keratinocytes, melanoma, and fibroblast incubated with Hypericum extracts or their isolated compounds have been utilised as useful models to determine the toxicity or the concentrations that would produce a toxic effect (Bridi et al., 2017; Gaid et al., 2019; Kurt-celep et al., 2020). Toxicity/safety data for most Hypericum species as cosmeceutical ingredients is significantly deficient due to the lack of a relevant pharmacological/toxicological approach. An expert panel reviewed the safety of seven $H$. perforatum derived ingredients (whole-plant extract, flower extract, flower/leaf extract, flower/leaf/stem extract, flower/twig extract, leaf extract, and $H$. perforatum oil) (Becker et al., 2014). H. perforatum extract (CAS No. 84082-80-4) and $H$. perforatum oil (CAS No. 68917-49-7) are used in the development of several formulations, including skincare products, shampoos, and bath products. The Cosmetic Ingredient Review (CIR) Expert Panel evaluated the acute toxicity, including erythema, oedema formation, and changes in blood chemistry. The results showed that the active ingredients were not irritants or sensitizers, presenting no ocular irritation in the eye and genotoxicity. The authors concluded that the ingredients were safe for use in cosmetics and personal care products, even though no carcinogenicity, reproductive, and developmental toxicity data were available at the time. To the authors' best knowledge, only $H$. perforatum among the several Hypericum species has been submitted to these detailed toxicological studies to determine their safe use as cosmetic ingredients.

\section{Hypericum-derived products}

\subsection{Patents}

Investments in $R \& D$ activities are also related to the expectation of 
obtaining intellectual rights over innovative findings and results; this is no less true for research on several Hypericum species and their related compounds application as cosmetic or cosmeceutical ingredients. Scientific evidence in the literature has shown the vast cosmeceutical potential of Hypericum species. However, these findings are still a long way from translating into commercially available products and as such, patent publications serve as essential resources to register the innovation and protect their inventors. Comprehensive analysis on the patent technologies produced in the last decade (Espacenet ${ }^{\circledR}$, PatentScope $\AA$, and Google Patents $\left.{ }^{\circledR}\right)$ using the keyword Hypericum, and concerning cosmetics and cosmeceuticals, are presented in Table 2. The majority of Hypericum patent technologies related to cosmetic and cosmeceutical applications belong to $H$. perforatum species. The growing power of Asian traditional medicine, as well as its large population, makes this region highly relevant in novel cosmeceutical technologies. Besides, countries such as Spain, USA, Russia, and Latvia also presented interesting patent technologies related to Hypericum because of the multifunctional bioactive properties and potency of the Hypericum cultivars found in these countries. Most of the innovative technologies shown in Table 2 is related to the development of natural-based cosmetic

Table 2

A decade summary of some Hypericum species patented as cosmetic ingredients.

\begin{tabular}{|c|c|c|c|c|}
\hline $\begin{array}{l}\text { Patent Number and } \\
\text { Country }\end{array}$ & $\begin{array}{l}\text { Approval } \\
\text { Year }\end{array}$ & $\begin{array}{l}\text { Hypericum species or } \\
\text { isolated metabolites }\end{array}$ & Patent Tittle & Patent Brief Details \\
\hline $\begin{array}{l}\text { US9238153B2 } \\
\text { USA }\end{array}$ & 2016 & $\begin{array}{l}\text { Hypericin }(H . \\
\text { perforatum) }\end{array}$ & $\begin{array}{l}\text { Transoral methods and compositions for wrinkle } \\
\text { reduction and cosmetic lip and facial } \\
\text { augmentation. }\end{array}$ & $\begin{array}{l}\text { This patent relates the anti-ageing potential of several natural } \\
\text { ingredients as protective barriers to the ECM, specifically to } \\
\text { reduce wrinkle appearance. }\end{array}$ \\
\hline $\begin{array}{l}\text { KR20160048844A } \\
\text { South Korea }\end{array}$ & 2016 & H. perforatum & $\begin{array}{l}\text { Product comprising a plant for medicinal, } \\
\text { cosmetic, colouring or dermatologic use. }\end{array}$ & $\begin{array}{l}\text { This patent relates to a product made from different plant } \\
\text { extracts to suppress skin surface cracks, dryness, skin } \\
\text { exfoliation, and burn. The different plant extracts were also } \\
\text { utilised as important source of natural colourants (yellow or } \\
\text { orange colour). }\end{array}$ \\
\hline $\begin{array}{l}\text { CN105585601B } \\
\text { China }\end{array}$ & 2018 & H. erectum & $\begin{array}{l}\text { Anti-aging composition for external application } \\
\text { and its manufacturing method. }\end{array}$ & $\begin{array}{l}\text { This invention relates to the utilisation of different plant } \\
\text { extracts to improve skin appearances, reduce wrinkle } \\
\text { associated with ageing, and maintain the barrier function of the } \\
\text { skin. }\end{array}$ \\
\hline $\begin{array}{l}\text { US20170112756A1 } \\
\text { USA }\end{array}$ & 2017 & H. forrestii & $\begin{array}{l}\text { Topical skin care formulations comprising plant } \\
\text { extracts }\end{array}$ & $\begin{array}{l}\text { This patent relates to the utilisation of plant extracts } \\
\text { (H. forrestii) with multifunctional properties such as TNF- } \alpha \text {, } \\
\text { antioxidant, and tyrosinase inhibitors. }\end{array}$ \\
\hline $\begin{array}{l}\text { KR101979462B1 } \\
\text { South Korea }\end{array}$ & 2019 & H. perforatum & Nanocapsules containing microemulsions. & $\begin{array}{l}\text { Polymer nanocapsule based delivery systems including } \\
\text { microemulsions were developed using hydrophilic active } \\
\text { ingredients from different plant extracts as cosmetic } \\
\text { ingredients. }\end{array}$ \\
\hline $\begin{array}{l}\text { ES2384060B1 } \\
\quad \text { Spain }\end{array}$ & 2013 & H. perforatum & Lipid nanoparticles capsules & $\begin{array}{l}\text { Solid lipid nanoparticles (SLN) and nanostructured lipid } \\
\text { carriers (NLC) were developed to encapsulated active } \\
\text { ingredients from plants with strong healing, re- } \\
\text { epithelialization, anti-inflammatory and antioxidant properties }\end{array}$ \\
\hline $\begin{array}{l}\text { US9056063B2 } \\
\text { USA }\end{array}$ & 2015 & H. perforatum & Natural sunscreen composition & $\begin{array}{l}\text { Because certain natural ingredients are known to have } \\
\text { sunscreen properties, this patent describes different sunscreen } \\
\text { formulations with natural extracts up to } 0.001-36 \% \mathrm{w} \text {, } \\
\text { prepared from cosmetically acceptable ingredients. }\end{array}$ \\
\hline $\begin{array}{l}\text { KR20120058830A } \\
\text { South Korea }\end{array}$ & 2012 & H. perforatum & $\begin{array}{l}\text { Cosmetic composition to promote the stemness } \\
\text { of adipose-derived stem cells and proliferating } \\
\text { skin cell containing Hypericum extracts. }\end{array}$ & $\begin{array}{l}\text { This patent describes an active principle containing a Hypericum } \\
\text { extract as stem cell growth and skin cell proliferation } \\
\text { promotors, thereby enhancing the regeneration of the } \\
\text { epidermis. }\end{array}$ \\
\hline $\begin{array}{l}\text { EP3135341A1 } \\
\quad \text { Latvia }\end{array}$ & 2017 & H. hirsutum & $\begin{array}{l}\text { Cosmetic skin whitening compositions } \\
\text { containing extracts derived from in vitro } \\
\text { propagated } H \text {. hirsutum. }\end{array}$ & $\begin{array}{l}\text { This invention describes the skin whitening potential of a } \\
\text { hydroethanolic extract derived from in vitro (shoot cultures } \\
\text { with no growth regulators added) cultivated } H \text {. hirsutum. }\end{array}$ \\
\hline $\begin{array}{l}\text { ES2416804A1 } \\
\quad \text { Spain }\end{array}$ & 2013 & H. perforatum & $\begin{array}{l}\text { Composition of natural products for topical } \\
\text { application. }\end{array}$ & $\begin{array}{l}\text { This patent describes a topical formulation in the form of gel, } \\
\text { emulsion, and cream functionalised with bioactive ingredients } \\
\text { (Portulaca oleracea, H. perforatum, Triticum aestivum, Malva spp., } \\
\text { Urtica urens, and Arnica montana), which can be used in burns, } \\
\text { eroded skin, pressure ulcers, psoriasis lesions, and herpes zoster } \\
\text { skin lesions. }\end{array}$ \\
\hline $\begin{array}{l}\text { RU2646494C1 } \\
\text { Russia }\end{array}$ & 2018 & H. perforatum & $\begin{array}{l}\text { Cosmetic composition against inflammation on } \\
\text { skin for usage as part of the cosmetic products }\end{array}$ & $\begin{array}{l}\text { This patent describes a cosmetic formulation consisting of } \\
\text { glycyrrhizic acid and/or its derivative, glycerin, and water- } \\
\text { glycerin extracts of } H \text {. perforatum utilised to suppress skin } \\
\text { inflammation. }\end{array}$ \\
\hline $\begin{array}{l}\text { EP1987810B1 } \\
\text { Japan }\end{array}$ & 2017 & H. perforatum & $\begin{array}{l}\text { External preparation for skin containing } \\
\text { flavanone derivative }\end{array}$ & $\begin{array}{l}\text { This patent describes a topical preparation containing } \\
\text { flavanone derivatives obtained from different plant extract with } \\
\text { excellent wound healing properties and a strong remodelling } \\
\text { action of the collagen fibre bundle. }\end{array}$ \\
\hline $\begin{array}{l}\text { KR101965032B1 } \\
\text { South Korea }\end{array}$ & 2019 & H. ascyron & $\begin{array}{l}\text { Cosmetic Composition comprising extract of } \\
\text { Hypericum ascyron }\end{array}$ & $\begin{array}{l}\text { This invention describes a cosmetic preparation containing } \\
\text { Hypericum extract as an active ingredient with strong } \\
\text { antioxidant, anti-hyaluronidase, anti-tyrosinase, anti- } \\
\text { collagenase, and anti-elastase activity. The final formulation } \\
\text { prevents skin ageing due to its strong multifunctional } \\
\text { properties. }\end{array}$ \\
\hline $\begin{array}{l}\text { RU2491911C1 } \\
\text { Russia }\end{array}$ & 2013 & H. perforatum & Moisturising cream with solid lipid nanoparticles & $\begin{array}{l}\text { In this invention, a moisturising cream containing solid lipid } \\
\text { nanoparticles with biologically active propylene glycol extracts } \\
\text { of some medicinal plants. The final formulation improved skin } \\
\text { water holding capacity and elasticity. }\end{array}$ \\
\hline $\begin{array}{l}\text { CN104688610A } \\
\text { China }\end{array}$ & 2015 & H. monogynum & Natural plant frozen film facial mask & $\begin{array}{l}\text { The invention relates to a beauty skincare product formulated } \\
\text { with natural bioactive ingredients, which exhibit acne } \\
\text { removing properties and a strong moisturizing capacity. }\end{array}$ \\
\hline
\end{tabular}


formulations with multifunctional properties. These effects include wrinkle reduction, skin exfoliation, maintenance of skin barrier function, the inhibition of inflammatory mediators, wound healing, UV protection, epidermal cell regeneration, and inhibition of tyrosinase, collagenase, and elastase. The numerous patents published in recent years cover a broad spectrum of potential cosmeceutical applications, which can further promote research and innovative opportunities.

\subsection{Commercial products}

Several commercial products formulated using extracts or isolated compounds obtained from Hypericum species are currently available in the market and utilised either to facial/body care and cleansing. Alpaflor ${ }^{\circledR}$ Hypericum B is a multifunctional cosmetic product from DSM nutritional products Ltd, Switzerland, formulated with $H$. perforatum extract and other key ingredients involved in the battle against inflammation. It has anti-inflammatory, enzyme inhibitory, anti-microbial, radical-scavenging, and healing properties. Crodarom ${ }^{\circledR}$ ST John's Wort $\mathrm{O}$ is produced by Crodarom S.A.S., a company specialised in botanical extracts for personal care and cosmeceuticals based in France. It is a phytocosmetic formulation containing extracts from $\mathrm{H}$. perforatum and Olea europaea fruit oil extracts, which is responsible for soothing sensitive skin and suitable for dry skin. Phytoconcentrole ${ }^{\circledR}$ is an oilbased formulation containing $H$. Perforatum extract and functionalised with sunflower oil, soybean oil, and stabilisers. It is marketed by Symrise, a company based in Germany with over 60 years of experience in developing high-quality natural ingredients for beauty and personal care. Phytoconcentrole ${ }^{\circledR}$ helps to keep the skin smooth and induce the formation of a natural protective film due to its lipophilic components. Most commercial products formulated using extracts from Hypericum species involve $H$. perforatum, and as such, significant efforts must be made to improve the development of formulations derived from other Hypericum species. An exhaustive report in literature has identified species such as $H$. androsaemum, $H$. monogynum, $H$. olympicum, and H. scabrum, among others, as exciting cosmeceutical candidates due to their reported anti-inflammatory, wound healing, and anti-ageing properties.

\section{Concluding remarks and future perspectives}

The rising demand and increased awareness among consumers on the origin, safety, and environmental implications of some of the ingredients used in cosmetics and personal care products are stimulating the research on novel bioactive ingredients from natural sources. The current review was aimed at studying plants belonging to the Hypericum genus that present potential as cosmeceutical ingredients, together with a summary of the scientific evidence regarding their commercial exploitation. In the last decade, studies on the phytochemical composition and biological properties of several Hypericum species have been widely reported. Among them, H. perforatum was the most widely exploited concerning its chemical composition, biological properties, and potential use as cosmeceutical ingredients. Some of the multifunctional properties reported for most Hypericum plants include antiinflammatory, anti-tyrosinase, anti-collagenase, anti-elastase, UV photoprotective, and wound healing. The main constituents of the Hypericum species are naphthodianthrones, phloroglucinol derivatives, phenolic acids, and flavonoids. Despite this knowledge, studies elucidating their mechanism of action and the bioactive metabolites responsible for some of the ascribed biological properties are still deficient; therefore, more studies need to be conducted. One of the criteria postulated by Dr Albert Kligman, who regarded as the father of cosmeceutical science states that, before classifying an active molecule as a cosmeceutical ingredient, data on the skin permeation and penetration into the stratum corneum should be established, and the bioavailable concentration determined to ensure it is enough to have the desired cosmeceutical effect. However, studies on the transdermal delivery of the active components found in different Hypericum species is also significantly lacking in the literature. In the past, ethical issues have significantly contributed to the scarcity of in vitro and in vivo skin permeation studies; however, with recent advancement in cell biology and tissue engineering, cell culture-based human skin models have been developed and are commercially available. They include reconstructed human epidermis and several skin equivalents models such as EpiSkin ${ }^{\circledR}$, SkinEthic $\AA$, EpiDerm $\AA$, GraftSkin $\AA$, EpiDermFT $\AA$, and Pheninon $\AA$, among others. Skin permeation assessment is key to the successful development of new cosmeceutical formulation; and therefore, these models can be further utilised due to their strong in vivo correlation. Nanodelivery systems have been utilised as a distinctive and useful approach to overcome the limitations associated with natural biomolecules in cosmeceuticals. Several Hypericum derived ingredients have been loaded into nanocapsules and microparticles offering higher stability and improved efficacy, mainly in wound healing applications. Hence, new developments in other cosmeceutical areas such as antiaging and photoprotection, among others, could be further explored. The physical and chemical features of the skin are the support for a unique set of microorganisms, most of which are harmless or even beneficial to their host. Recent studies have suggested that aside from the gastrointestinal tract, skin harbours the most microbes in the human body; which implies that the composition of the skin microbiota can influence an individual's skin health and condition, including skin ageing. Some studies have highlighted candidate microbes and functional pathways that are important in preventing skin ageing and which could lead to a comprehensive understanding of age-related skin microbiome characteristics. Ample evidence has been emerging on the activity of natural biomolecules on the modulation of the skin microbial population composition or activity. Hence, further work could be performed to understand the effect of Hypericum extracts and their isolated compounds as potential skin microbiome modulators; thereby, offering innovative dimension to this genus properties. The studies presented in this review reflect the enormous scientific findings that have been invested in the application of Hypericum species as sources of pharmacologically active metabolites for exploitation in the growing cosmeceutical industry.

\section{Declaration of Competing Interest}

The authors report no declarations of interest.

\section{Acknowledgements}

The authors are grateful to the Foundation for Science and Technology (FCT, Portugal) for financial support through national funds FCT/MCTES to CIMO (UIDB/00690/2020). L. Barros is also thankful to FCT through the institutional scientific employment program-for her contract. Ana Rita Silva is also grateful to FCT for her Doctoral Grant (SFRH/BD/145834/2019). Oludemi Taofiq is grateful to the European Regional Development Fund (ERDF) through the Regional Operational Program North 2020, within the scope of Project Mobilizador Norte-010247-FEDER-024479: ValorNatural ${ }^{\circledR}$ for his contract.

\section{References}

Altun, M.L., Yilmaz, B.S., Orhan, I.E., Citoglu, G.S., 2013. Assessment of cholinesterase and tyrosinase inhibitory and antioxidant effects of Hypericum perforatum L. (St. John's wort). Ind. Crops Prod. 43, 87-92. https://doi.org/10.1016/j. indcrop.2012.07.017.

Ando, H., Matsui, M.S., Ichihashi, M., 2010. Quasi-drugs developed in Japan for the prevention or treatment of hyperpigmentary disorders. Int. J. Mol. Sci. 11, 2566-2575. https://doi.org/10.3390/ijms11072699.

Aneke, C.I., Otranto, D., Cafarchia, C., 2018. Therapy and antifungal susceptibility profile of microsporum canis. J. Fungi Basel (Basel) 4, 1-14. https://doi.org/ 10.3390/jof4030107.

Antognoni, F., Lianza, M., Poli, F., Buccioni, M., Santinelli, C., Caprioli, G., Iannarelli, R., Lupidi, G., Maggi, F., Damiani, E., Beghelli, D., Alunno, A., 2017. Polar extracts from the berry-like fruits of Hypericum androsaemum L. as a promising ingredient in skin 
care formulations. J. Ethnopharmacol. 195, 255-265. https://doi.org/10.1016/j. jep.2016.11.029.

Arndt, S., Haag, S.F., Kleemann, A., Lademann, J., Meinke, M.C., 2013. Radical protection in the visible and infrared by a hyperforin-rich cream - in vivo versus ex vivo methods. Exp. Dermatol. 22, 354-357. https://doi.org/10.1111/exd.12124.

Aygül, A., Şerbetçi, T., 2020. The antibacterial and antivirulent potential of Hypericum lydium against Staphylococcus aureus: inhibition of growth, biofilm formation, and hemolytic activity. Eur. J. Integr. Med. 35, 101061 https://doi.org/10.1016/j. eujim.2020.101061.

Bagdonaitž, E., Mártonfi, P., Repčák, M., Labokas, J., 2010. Variation in the contents of pseudohypericin and hypericin in Hypericum perforatum from Lithuania. Biochem. Syst. Ecol. 38, 634-640. https://doi.org/10.1016/j.bse.2010.08.005.

Barbieri, R., Coppo, E., Marchese, A., Daglia, M., Sobarzo-Sánchez, E., Nabavi, S.F., Nabavi, S.M., 2017. Phytochemicals for human disease: an update on plant-derived compounds antibacterial activity. Microbiol. Res. 196, 44-68. https://doi.org/ 10.1016/j.micres.2016.12.003.

Barros, L., Morales, P., Carvalho, A.M., Ferreira, I.C.F.R., 2016. Antioxidant potential of wild plant foods. Mediterranean Wild Edible Plants: Ethnobotany and Food Composition Tables. Springer, New York, pp. 209-232. https://doi.org/10.1007/ 978-1-4939-3329-7_10.

Battaglia, L., Ugazio, E., 2019. Lipid nano- and microparticles: an overview of patentrelated research. J. Nanomater. 2019, 1-22. https://doi.org/10.1155/2019/ 2834941, 2834941.

Becker, L.C., Bergfeld, W.F., Belsito, D.V., Hill, R.A., Klaassen, C.D., Liebler, D.C., Marks, J.G., Shank, R.C., Slaga, T.J., Snyder, P.W., Andersen, F.A., Gill, L.J., 2014. Amended safety assessment of Hypericum perforatum-derived ingredients as used in cosmetics. Int. J. Toxicol. 33, 5S-23S. https://doi.org/10.1177/ 1091581814533354.

Beißner, N., Bolea Albero, A., Füller, J., Kellner, T., Lauterboeck, L., Liang, J., Böl, M., Glasmacher, B., Müller-Goymann, C.C., Reichl, S., 2018. Improved in vitro models for preclinical drug and formulation screening focusing on 2D and 3D skin and cornea constructs. Eur. J. Pharm. Biopharm. 126, 57-66. https://doi.org/10.1016/j. ejpb.2017.11.014.

Bender, O., Llorent-Martínez, E.J., Zengin, G., Mollica, A., Ceylan, R., Molina-García, L., Luisa Fernández-de Córdova, M., Atalay, A., 2018. Integration of in vitro and in silico perspectives to explain chemical characterization, biological potential and anticancer effects of Hypericum salsugineum: a pharmacologically active source for functional drug formulations. PLoS One 13, 1-21. https://doi.org/10.1371/journal. pone.0197815.

Bertoli, A., Çirak, C., Seyis, F., 2015. Hypericum origanifolium Willd.: the essential oil composition of a new valuable species. Ind. Crops Prod. 77, 676-679. https://doi, org/10.1016/j.indcrop.2015.08.014.

Bilal, M., Iqbal, H.M.N., 2019. An insight into toxicity and human-health-related adverse consequences of cosmeceuticals - a review. Sci. Total Environ. 670, 555-568. https://doi.org/10.1016/j.scitotenv.2019.03.261.

Blom van Staden, A., De Canha, M., Nqephe, M., Rademan, S., Kumar, V., Lall, N., 2017 Potential medicinal plants for progressive macular hypomelanosis. S. Afr. J. Bot. 111, 346-357. https://doi.org/10.1016/j.sajb.2017.04.007.

Boran, R., 2018. Investigations of anti-aging potential of Hypericum origanifolium Willd. for skincare formulations. Ind. Crops Prod. 118, 290-295. https://doi.org/10.1016/ j.indcrop.2018.03.058.

Bridi, H., Beckenkamp, A., Ccana-Ccapatinta, G.V., de Loreto Bordignon, S.A., Buffon, A., von Poser, G.L., 2017. Characterization of phloroglucinol-enriched fractions of brazilian Hypericum species and evaluation of their effect on human keratinocytes proliferation. Phyther. Res. 31, 62-68. https://doi.org/10.1002/ptr.5727.

Bridi, H., Beckenkamp, A., Maurmann, N., Elingson, B., Buffon, A., Pranke, P., von Poser, G.L., 2019. Phloroglucinol derivatives from Hypericum species induce in vitro proliferation of cells involved in the wound healing process. Nat. Prod. Res. 0, 1-5. https://doi.org/10.1080/14786419.2019.1698576.

Caprioli, G., Alunno, A., Beghelli, D., Bianco, A., Bramucci, M., Frezza, C., Iannarelli, R., Papa, F., Quassinti, L., Sagratini, G., Tirillini, B., Venditti, A., Vittori, S., Maggi, F., 2016. Polar constituents and biological activity of the berry-like fruits from Hypericum androsaemum L. Front. Plant Sci. 7, 1-12. https://doi.org/10.3389/ fpls.2016.00232.

Carocho, M., Ferreira, I.C.F.R., 2013. A review on antioxidants, prooxidants and related controversy: natural and synthetic compounds, screening and analysis methodologies and future perspectives. Food Chem. Toxicol. 51, 15-25. https://doi org /10.1016/j.fct.2012.09.021.

Carradori, Simone, Chimenti, Paola, Secci, Daniela, Bolasco, Adriana, Carradori, S., Chimenti, P., Secci, D., Bolasco, A., 2014. Selective MAO-B inhibitors: a lesson from natural products Serotonin 5-HTP 5-Hydroxytryptophan 6-OHDA 6Hydroxydopamine. Mol. Divers. 18, 219-243. https://doi.org/10.1007/s11030-0139490-6.

Castro, F.C.B., Magre, A., Cherpinski, R., Zelante, P.M., Neves, L.M.G., Esquisatto, M.A M., Mendonça, F.A.S., Santos, G.M.T., 2012. Effects of microcurrent application alone or in combination with topical Hypericum perforatum L. and Arnica montana L. on surgically induced wound healing in Wistar rats. Homeopathy 101, 147-153. https://doi.org/10.1016/j.homp.2012.05.006.

Celep, E., İnan, Y., Akyüz, S., Yesilada, E., 2017. The bioaccessible phenolic profile and antioxidant potential of Hypericum perfoliatum L. after simulated human digestion. Ind. Crops Prod. 109, 717-723. https://doi.org/10.1016/j.indcrop.2017.09.032.

Chaowattanapanit, S., Silpa-archa, N., Kohli, I., Lim, H.W., Hamzavi, I., 2017. Postinflammatory hyperpigmentation: a comprehensive overview: treatment options and prevention. J. Am. Acad. Dermatol. 77, 607-621. https://doi.org/10.1016/j. jaad.2017.01.036.
Charles Dorni, A.I., Amalraj, A., Gopi, S., Varma, K., Anjana, S.N., 2017. Novel cosmeceuticals from plants-an industry guided review. J. Appl. Res. Med. Aromat. Plants 7, 1-26. https://doi.org/10.1016/j.jarmap.2017.05.003.

Chen, J.J., Chen, H.J., Lin, Y.L., 2014. Novel polyprenylated phloroglucinols from hypericum sampsonii. Molecules 19, 19836-19844. https://doi.org/10.3390/ molecules191219836.

Chen, Y., Xian, Y., Lai, Z., Loo, S., Chan, W.Y., Lin, Z.X., 2016. Anti-inflammatory and anti-allergic effects and underlying mechanisms of Huang-Lian-Jie-Du extract: Implication for atopic dermatitis treatment. J. Ethnopharmacol. 185, 41-52. https:// doi.org/10.1016/j.jep.2016.03.028.

Chen, Q., Di, L., Zhang, Y., Li, N., 2020. Chemical constituents with cytotoxic and antiinflammatory activity in Hypericum sampsonii and the antitumor potential under the view of cancer-related inflammation. J. Ethnopharmacol. 259, 1129482 https://doi. org/10.1016/j.jep.2020.112948.

Chiocchio, I., Mandrone, M., Sanna, C., Maxia, A., Tacchini, M., Poli, F., 2018. Screening of a hundred plant extracts as tyrosinase and elastase inhibitors, two enzymatic targets of cosmetic interest. Ind. Crops Prod. 122, 498-505. https://doi.org/ 10.1016/j.indcrop.2018.06.029.

Çirak, C., Radušienè, J., Ivanauskas, L., Janulis, V., 2007. Variation of bioactive secondary metabolites in Hypericum origanifolium during its phenological cycle. Acta Physiol. Plant. 29, 197-203. https://doi.org/10.1007/s11738-007-0024-7.

Cirak, C., Radusiene, J., Jakstas, V., Ivanauskas, L., Seyis, F., Yayla, F., 2016. Secondary metabolites of seven Hypericum species growing in Turkey. Pharm. Biol. 54, 2244-2253. https://doi.org/10.3109/13880209.2016.1152277.

Crockett, S.L., Robson, N.K.B., 2011. Taxonomy and Chemotaxonomy of the genus Hypericum. Med. Aromat. Plant Sci. Biotechnol. 5, 1-26.

Darias, V., Bravo, L., Barquin, E., Herrera, D.M., Fraile, C., 1986. Contribution to the ethnopharmacological study of the Canary Islands. J. Ethnopharmacol. 15, 169-193. https://doi.org/10.1016/0378-8741(86)90154-6.

Del Monte, D., De Martino, L., Marandino, A., Fratianni, F., Nazzaro, F., De Feo, V., 2015. Phenolic content, antimicrobial and antioxidant activities of Hypericum perfoliatum L. Ind. Crops Prod. 74, 342-347. https://doi.org/10.1016/j.indcrop.2015.04.036.

Di Meo, S., Reed, T., Venditti, P., Victor, V., 2016. Role of ROS and RNS sources in physiological and pathological conditions. Oxid. Med. Cell. Longev. 2016, 1-44. https://doi.org/10.1155/2016/1245049, 1245049.

Dikmen, M., Öztürk, Y., Sagratini, G., Ricciutelli, M., Vittori, S., Maggi, F., 2010. Evaluation of the wound healing potentials of two subspecies of Hypericum perforatum on cultured NIH3T3 fibroblasts. Phyther. Res. 25, 208-214. https://doi. org/10.1002/ptr.3243.

Dominguez, S., Mackert, G.A., Dobke, M.K., 2017. Nanotechnology to enhance transdermal delivery of hydrophilic humectants for improved skin care: a model for therapeutic applications. Nanostructures for Drug Delivery. Elsevier, pp. 919-939. https://doi.org/10.1016/b978-0-323-46143-6.00029-4.

Dresler, S., Kováčik, J., Strzemski, M., Sowa, I., Wójciak-Kosior, M., 2018. Methodological aspects of biologically active compounds quantification in the genus Hypericum. J. Pharm. Biomed. Anal. 155, 82-90. https://doi.org/10.1016/j. jpba.2018.03.048.

Eğri, Ö., Erdemir, N., Gevrek, F., 2020. Effect of H. perforatum oil containing membranes on the second degree burn wounds in rats. Mater. Today Commun. 24, 100954 https://doi.org/10.1016/j.mtcomm.2020.100954.

Elgorashi, E.E., McGaw, L.J., 2019. African plants with in vitro anti-inflammatory activities: a review. S. Afr. J. Bot. 126, 142-169. https://doi.org/10.1016/j. sajb.2019.06.034.

Hypericum: the Genus Hypericum. Medicinal and Aromatic Plants - Industrial Profiles Series. In: Ernst, E. (Ed.), 2003. Taylor and Francis, London \& New York.

Eroglu Ozkan, E., Yilmaz Ozden, T., Ozsoy, N., Mat, A., 2018. Evaluation of chemical composition, antioxidant and anti-acetylcholinesterase activities of Hypericum neurocalycinum and Hypericum malatyanum. S. Afr. J. Bot. 114, 104-110. https://doi. org/10.1016/j.sajb.2017.10.022.

Ersoy, E., Eroglu Ozkan, E., Boga, M., Yilmaz, M.A., Mat, A., 2019. Anti-aging potential and anti-tyrosinase activity of three Hypericum species with focus on phytochemical composition by LC-MS/MS. Ind. Crops Prod. 141, 111735 https://doi.org/10.1016/ j.indcrop.2019.111735.

Fernández-Moriano, C., Gómez-Serranillos, M.P., Crespo, A., 2016. Antioxidant potential of lichen species and their secondary metabolites. A systematic review. Pharm. Biol. 54, 1-17. https://doi.org/10.3109/13880209.2014.1003354.

Ferreira, I., Barros, L., Abreu, R., 2009. Antioxidants in wild mushrooms. Curr. Med. Chem. 16, 1543-1560. https://doi.org/10.2174/092986709787909587.

França, H.S., Rocha, L., Fernande, C.P., Ruiz, A.L.T.G., de Carvalho, J.E., 2013. Antiproliferative activity of the hexanic extract and phloroglucinols from Hypericum brasiliense. Brazilian J. Pharmacogn. 23, 844-847. https://doi.org/10.1590/S0102695X2013000500018.

Füller, J., Müller-Goymann, C.C., 2018. Anti-proliferative and anti-migratory effects of hyperforin in 2D and 3D artificial constructs of human dermal fibroblasts - a new option for hypertrophic scar treatment? Eur. J. Pharm. Biopharm. 126, 108-114. https://doi.org/10.1016/j.ejpb.2017.03.003.

Gaid, M., Füller, J., Müller-Goymann, C., 2019. The petroleum ether extract from Hypericum perforatum root cultures exhibits potent antiproliferative activity in human keratinocytes and fibroblasts. Planta Med. 85, 591-598. https://doi.org/ 10.1055/a-0806-7735.

Galeotti, N., 2017. Hypericum perforatum (St John's wort) beyond depression: a therapeutic perspective for pain conditions. J. Ethnopharmacol. 200, 136-146. https://doi.org/10.1016/j.jep.2017.02.016.

Ganceviciene, R., Liakou, A.I., Theodoridis, A., Makrantonaki, E., Zouboulis, C.C., 2012. Skin anti-aging strategies. Dermatoendocrinol. 4, 308-319. https://doi.org/ 10.4161/derm.22804. 
Gao, X.H., Zhang, L., Wei, H., Chen, H.D., 2008. Efficacy and safety of innovative cosmeceuticals. Clin. Dermatol. 26, 367-374. https://doi.org/10.1016/j. clindermatol.2008.01.013.

García-Pérez, P., Barreal, M.E., Rojo-De Dios, L., Cameselle-Teijeiro, J.F., Gallego, P.P., 2018. Bioactive natural products from the genus Kalanchoe as cancer chemopreventive agents: a review, in: studies in natural products chemistry. Stud. Nat. Prod. Chem. 49-84. https://doi.org/10.1016/B978-0-444-64183-0.00002-6. Elsevier B.V.

Germ, M., Stibilj, V., Kreft, S., Gaberščik, A., Kreft, I., 2010. Flavonoid, tannin and hypericin concentrations in the leaves of St. John's wort (Hypericum perforatum L.) are affected by UV-B radiation levels. Food Chem. 122, 471-474. https://doi.org/ 10.1016/j.foodchem.2010.03.008.

Ghuman, S., Ncube, B., Finnie, J.F., McGaw, L.J., Mfotie Njoya, E., Coopoosamy, R.M., Van Staden, J., 2019. Antioxidant, anti-inflammatory and wound healing properties of medicinal plant extracts used to treat wounds and dermatological disorders. S. Afr. J. Bot. 126, 232-240. https://doi.org/10.1016/j.sajb.2019.07.013.

Giudice, E., Crinò, C., Salerno, G., Rizzo, M., Levanti, M., Di Pietro, S., 2017. Evaluation of wound healing activity of St. John's Wort (Hypericum perfoliatum) in horses. Comp. Clin. Path. 26, 611-615. https://doi.org/10.1007/s00580-017-2426-2.

Güneş, S., Tihmınlıoglu, F., 2017. Hypericum perforatum incorporated chitosan films as potential bioactive wound dressing material. Int. J. Biol. Macromol. 102, 933-943. https://doi.org/10.1016/j.ijbiomac.2017.04.080.

Haag, S.F., Tscherch, K., Arndt, S., Kleemann, A., Gersonde, I., Lademann, J., Rohn, S., Meinke, M.C., 2014. Enhancement of skin radical scavenging activity and stratum corneum lipids after the application of a hyperforin-rich cream. Eur. J. Pharm. Biopharm. 86, 227-233. https://doi.org/10.1016/j.ejpb.2013.06.016.

Hammer, K.D.P., Yum, M.Y., Dixon, P.M., Birt, D.F., 2010. Identification of JAK-STAT pathways as important for the anti-inflammatory activity of a Hypericum perforatum fraction and bioactive constituents in RAW 264.7 mouse macrophages. Phytochemistry 71, 716-725. https://doi.org/10.1016/j.phytochem.2010.02.006.

Herman, A., 2019. Antimicrobial ingredients as preservative booster and components of self-preserving cosmetic products. Curr. Microbiol. 76, 744-754. https://doi.org/ 10.1007/s00284-018-1492-2.

Huang, H.S., Liaw, E.T., 2017. Extraction optimization of flavonoids from Hypericum formosanum and matrix metalloproteinase-1 inhibitory activity. Molecules 22, 1-12. https://doi.org/10.3390/molecules22122172.

Huang, N., Rizshsky, L., Hauck, C., Nikolau, B.J., Murphy, P.A., Birt, D.F., 2011 Identification of anti-inflammatory constituents in Hypericum perforatum and Hypericum gentianoides extracts using RAW 264.7 mouse macrophages. Phytochemistry 72, 2015-2023. https://doi.org/10.1016/j. phytochem.2011.07.016.

Huang, H., Hsu, T., Chao, H., Chen, C., Chiu, S., Chang, T., 2014. Inhibition of melanogenesis in murine melanoma cells by Agaricus brasiliensis methanol extract and anti-reactive oxygen species (ROS) activity. African J. Microbiol. Res. 8, 519-524. https://doi.org/10.5897/AJMR2013.6271.

Irina Prisăcaru, A., Andrițoiu, C.V., Andriescu, C., Hăvârneanu, E.C., Popa, M., M Motoc, A.G., Sava, A., 2013. Evaluation of the wound-healing effect of a novel Hypericum perforatum ointment in skin injury. Rom. J. Morphol. Embryol. 54, 1053-1059.

Jabeur, I., Tobaldini, F., Martins, N., Barros, L., Martins, I., Calhelha, R.C., Henriques, M., Silva, S., Achour, L., Santos-Buelga, C., Ferreira, I.C.F.R., 2016. Bioactive properties and functional constituents of Hypericum androsaemum L.: a focus on the phenolic profile. Food Res. Int. 89, 422-431. https://doi.org/10.1016/j.foodres.2016.08.040.

Jarić, S., Kostić, O., Mataruga, Z., Pavlović, D., Pavlović, M., Mitrović, M., Pavlović, P. 2018. Traditional wound-healing plants used in the Balkan region (Southeast Europe). J. Ethnopharmacol. 211, 311-328. https://doi.org/10.1016/j. jep.2017.09.018.

Jia, X., Wu, Y., Lei, C., Yu, Y., Li, Jianqi, Li, Jingya, Hou, A., 2019. Hyperinoids A and B, two polycyclic meroterpenoids from Hypericum patulum. Chin. Chem. Lett. 31, 1263-1266. https://doi.org/10.1016/j.cclet.2019.10.014.

Jin, X.N., Yan, E.Z., Wang, H.M., Sui, H.J., Liu, Z., Gao, W., Jin, Y., 2016. Hyperoside exerts anti-inflammatory and anti-arthritic effects in LPS-stimulated human fibroblast-like synoviocytes in vitro and in mice with collagen-induced arthritis. Acta Pharmacol. Sin. 37, 674-686. https://doi.org/10.1038/aps.2016.7.

Jin, D.X., He, J.F., Zhang, K.Q., Luo, X.G., Zhang, T.C., 2019. EtOAc extract of $H$. attenuatum Choisy inhibits inflammation by suppressing the NF- $\mathrm{KB}$ and MAPK pathways and modulating the gut microbiota. Phytomedicine 57, 292-304. https:// doi.org/10.1016/j.phymed.2018.12.037.

Juliano, C., Magrini, G., 2018. Methylglyoxal, the major antibacterial factor in manuka honey: an alternative to preserve natural cosmetics? Cosmetics $6,1-13$. https://doi. org $/ 10.3390 /$ cosmetics6010001.

Karioti, A., Bilia, A.R., 2010. Hypericins as potential leads for new therapeutics. Int. J. Mol. Sci. 11, 562-594. https://doi.org/10.3390/ijms11020562.

Kerdudo, A., Burger, P., Merck, F., Dingas, A., Rolland, Y., Michel, T., Fernandez, X. 2016. Development of a natural ingredient - natural preservative: a case study. Comptes Rendus Chim. 19, 1077-1089. https://doi.org/10.1016/j.crci.2016.06.004.

Kim, S.J., Um, J.Y., Hong, S.H., Lee, J.Y., 2011. Anti-inflammatory activity of hyperoside through the suppression of nuclear factor- $\mathrm{kB}$ activation in mouse peritoneal macrophages. Am. J. Chin. Med. 39, 171-181. https://doi.org/10.1142/ S0192415X11008737.

Kim, H., Kim, S.W., Seok, K.H., Hwang, C.W., Ahn, J.C., Jin, J.O., Kang, H.W., 2018. Hypericin-assisted photodynamic therapy against anaplastic thyroid cancer. Photodiagn. Photodyn. Ther. 24, 15-21. https://doi.org/10.1016/j. pdpdt.2018.08.008.

Kizhedath, A., Wilkinson, S., Glassey, J., 2019. Toxicology in vitro assessment of hepatotoxicity and dermal toxicity of butyl paraben and methyl paraben using
HepG2 and HDFn in vitro models. Toxicol. In Vitro 55, 108-115. https://doi.org/ 10.1016/j.tiv.2018.12.007.

Kladar, N., Srđenović, B., Grujić, N., Bokić, B., Rat, M., Anačkov, G., Božin, B., 2015. Ecologically and ontogenetically induced variations in phenolic compounds and biological activities of Hypericum maculatum subsp. maculatum. Hypericaceae. Rev. Bras. Bot. 38, 703-715. https://doi.org/10.1007/s40415-015-0177-3.

Kleemann, B., Loos, B., Scriba, T.J., Lang, D., Davids, L.M., 2014. St John's Wort (Hypericum perforatum L.) photomedicine: hypericin-photodynamic therapy induces metastatic melanoma cell death. PLoS One 9, 103762. https://doi.org/10.1371/ journal.pone.0103762.

Klemow, K.M., Bartlow, A., Crawford, J., Kocher, N., Shah, J., Ritsick, M., 2011. Medical attributes of St. John's Wort (Hypericum Perforatum). Herbal Medicine: Biomolecular and Clinical Aspects, second edition. CRC Press, pp. 211-237. https://doi.org/ 10.1201/b10787-12.

Kočevar Glavač, N., Lunder, M., 2018. Preservative efficacy of selected antimicrobials of natural origin in a cosmetic emulsion. Int. J. Cosmet. Sci. 40, 276-284. https://doi. org/10.1111/ics.12461.

Kurt-celep, İ., Celep, E., Akyüz, S., Hakan, T., Akayd, G., Telci, D., Yesilada, E., 2020. Hypericum olympicum L. Recovers DNA damage and prevents MMP - 9 activation induced by UVB in human dermal fibroblasts. J. Ethnopharmacol. 246, 112202 https://doi.org/10.1016/j.jep.2019.112202.

Lee, C.-M., 2016. Fifty years of research and development of cosmeceuticals: a contemporary review. J. Cosmet. Dermatol. 15, 527-539. https://doi.org/10.1111/ jocd.12261.

Li, W., Sun, Y.N., Yan, X.T., Yang, S.Y., Choi, C.W., Hyun, J.W., Kang, H.K., Paek, K.Y., Kim, Y.H., 2013. Isolation of xanthones from adventitious roots of St. John's Wort (Hypericum perforatum L.) and their antioxidant and cytotoxic activities. Food Sci. Biotechnol. 22, 945-949. https://doi.org/10.1007/s10068-013-0168-8.

Li, Y.P., Hu, K., Yang, X.W., Xu, G., 2018. Antibacterial dimeric acylphloroglucinols from Hypericum japonicum. J. Nat. Prod. 81, 1098-1102. https://doi.org/10.1021/acs. jnatprod.8b00017.

Li, Y.R., Xu, W.J., Wei, S.S., Lu, W.J., Luo, J., Kong, L.Y., 2019a. Hyperbeanols F-Q, diverse monoterpenoid polyprenylated acylphloroglucinols from the flowers of Hypericum beanii. Phytochemistry 159, 56-64. https://doi.org/10.1016/j. phytochem.2018.12.005.

Li, Z.P., Kim, J.Y., Ban, Y.J., Park, K.H., 2019b. Human neutrophil elastase (HNE) inhibitory polyprenylated acylphloroglucinols from the flowers of Hypericum ascyron. Bioorg. Chem. 90, 103075 https://doi.org/10.1016/j.bioorg.2019.103075.

Li, Ying-Ying, Zhang, Y., Li, W., Wu, Z., Chen, N., Wang, G., Li, Yao-Lan, 2020. Isopropylpyrone and Phenylpyrones from the leaves of Hypericum monogynum. Chemistry Select 5, 2317-2321. https://doi.org/10.1002/slct.201903815.

Lima, A.M., Pizzol, C.D., Monteiro, F.B.F., Creczynski-Pasa, T.B., Andrade, G.P., Ribeiro, A.O., Perussi, J.R., 2013. Hypericin encapsulated in solid lipid nanoparticles: phototoxicity and photodynamic efficiency. J. Photochem. Photobiol. B, Biol. 125, 146-154. https://doi.org/10.1016/j.jphotobiol.2013.05.010.

Liu, X.N., Zhang, X.Q., Sun, J.S., 2007. Effects of cytokinins and elicitors on the production of hypericins and hyperforin metabolites in Hypericum sampsonii and Hypericum perforatum. Plant Growth Regul. 53, 207-214. https://doi.org/10.1007/ s10725-007-9220-0.

Liu, Y., Long, J., Liu, J., 2014. Mitochondrial free radical theory of aging: who moved my premise? Geriatr. Gerontol. Int. 14, 740-749. https://doi.org/10.1111/ggi.12296.

Liu, Y.Y., Ao, Z., Xue, G.M., Wang, X.B., Luo, J.G., Kong, L.Y., 2018. Hypatulone A, a homoadamantane-type acylphloroglucinol with an intricately caged core from Hypericum patulum. Org. Lett. 20, 7953-7956. https://doi.org/10.1021/acs. orglett.8b03523.

Llorent-Martínez, E.J., Zengin, G., Lobine, D., Molina-García, L., Mollica, A., Mahomoodally, M.F., 2018. Phytochemical characterization, in vitro and in silico approaches for three Hypericum species. New J. Chem. 42, 5204-5214. https://doi. org/10.1039/c8nj00347e.

Lomovsky, O.I., Lomovskiy, I.O., Orlov, D.V., 2017. Mechanochemical solid acid/base reactions for obtaining biologically active preparations and extracting plant materials. Green Chem Lett Rev. 10, 171-185. https://doi.org/10.1080/ 17518253.2017.1339832.

López, V., Les, F., Iannarelli, R., Caprioli, G., Maggi, F., 2016. Methanolic extract from red berry-like fruits of Hypericum androsaemum: chemical characterization and inhibitory potential of central nervous system enzymes. Ind. Crops Prod. 94, 363-367. https://doi.org/10.1016/j.indcrop.2016.09.007.

Mabona, U., Viljoen, A., Shikanga, E., Marston, A., Van Vuuren, S., 2013. Antimicrobial activity of southern African medicinal plants with dermatological relevance: from an ethnopharmacological screening approach, to combination studies and the isolation of a bioactive compound. J. Ethnopharmacol. 148, 45-55. https://doi.org/10.1016/ j.jep.2013.03.056.

Mahomoodally, M.F., Zengin, G., Zheleva-Dimitrova, D., Mollica, A., Stefanucci, A., Sinan, K.I., Aumeeruddy, M.Z., 2019. Metabolomics profiling, bio-pharmaceutical properties of Hypericum lanuginosum extracts by in vitro and in silico approaches. Ind. Crops Prod. 133, 373-382. https://doi.org/10.1016/j.indcrop.2019.03.033.

Mandrone, M., Lorenzi, B., Venditti, A., Guarcini, L., Bianco, A., Sanna, C., Ballero, M., Poli, F., Antognoni, F., 2015. Antioxidant and anti-collagenase activity of Hypericum hircinum L. Ind. Crops Prod. 76, 402-408. https://doi.org/10.1016/j. indcrop.2015.07.012.

Mann, T., Gerwat, W., Batzer, J., Eggers, K., Scherner, C., Wenck, H., Stäb, F., Hearing, V. J., Röhm, K.H., Kolbe, L., 2018. Inhibition of human tyrosinase requires molecular motifs distinctively different from mushroom tyrosinase. J. Invest. Dermatol. 138, 1601-1608. https://doi.org/10.1016/j.jid.2018.01.019. 
Mansour, S., Djebli, N., Ozkan, E.E., Mat, A., 2014. In vivo antiinflammatory activity and chemical composition of Hypericum scabroides. Asian Pac. J. Trop. Med. 7 S514-S520. https://doi.org/10.1016/S1995-7645(14)60283-2.

Mansouri, P., Mirafzal, S., Najafizadeh, P., Safaei-Naraghi, Z., Salehi-Surmaghi, M.H., Hashemian, F., 2017. The impact of topical Saint John's Wort (Hypericum perforatum) treatment on tissue tumor necrosis factor-alpha levels in plaque-type psoriasis: a pilot study. J. Postgrad. Med. 63, 215-220. https://doi.org/10.4103/ 0022-3859.201423.

Marques, C.M.D.G., MacNeil, S., 2016. Use of a tissue engineered human skin model to investigate the effects of wounding and of an anti-inflammatory on melanoma cell invasion. PLoS One 11. https://doi.org/10.1371/journal.pone.0156931.

Marrelli, M., Statti, G., Conforti, F., Menichini, F., 2016. New potential pharmaceutical applications of Hypericum species. Mini-Reviews Med. Chem. 16, 710-720. https:// doi.org/10.2174/1389557515666150709105844.

Marrelli, M., Statti, G., Conforti, F., 2019. Hypericum spp.: an update on the biological activities and metabolic profiles. Mini-Rev. Med. Chem. 20, 66-87. https://doi.org/ 10.2174/1389557519666190926120211.

Meinke, M.C., Schanzer, S., Haag, S.F., Casetti, F., Müller, M.L., Wölfle, U., Kleemann, A., Lademann, J., Schempp, C.M., 2012. In vivo photoprotective and anti-inflammatory effect of hyperforin is associated with high antioxidant activity in vitro and ex vivo. Eur. J. Pharm. Biopharm. 81, 346-350. https://doi.org/10.1016/j. ejpb.2012.03.002.

Moeini, A., Pedram, P., Makvandi, P., Malinconico, M., Gomez d'Ayala, G., 2020. Wound healing and antimicrobial effect of active secondary metabolites in chitosan-based wound dressings: a review. Carbohydr. Polym. 233, 115839 https://doi.org/ 10.1016/j.carbpol.2020.115839.

Moghadam, S.E., Moridi Farimani, M., Soroury, S., Ebrahimi, S.N., Jabbarzadeh, E., 2019. Hypermongone $C$ accelerates wound healing through the modulation of inflammatory factors and promotion of fibroblast migration. Molecules 24, 2022 https://doi.org/10.3390/molecules24102022.

Montoya, A., Daza, A., Muñoz, D., Ríos, K., Taylor, V., Cedeño, D., Vélez, I.D., Echeverri, F., Robledo, S.M., 2015. Development of a novel formulation with hypericin to treat cutaneous leishmaniasis based on photodynamic therapy in in vitro and in vivo studies. Antimicrob. Agents Chemother. 59, 5804-5813. https://doi.org/ 10.1128/AAC.00545-15.

Mukherjee, P.K., Biswas, R., Sharma, A., Banerjee, S., Biswas, S., Katiyar, C.K., 2018 Validation of medicinal herbs for anti-tyrosinase potential. J. Herb. Med. 14, 1-16. https://doi.org/10.1016/j.hermed.2018.09.002.

Nabavi, S.M., Nabavi, S.F., Sureda, A., Caprioli, G., Iannarelli, R., Sokeng, A.J.T., Braidy, N., Khanjani, S., Moghaddam, A.H., Atanasov, A.G., Daglia, M., Maggi, F., 2018. The water extract of tutsan (Hypericum androsaemum L.) red berries exerts antidepressive-like effects and in vivo antioxidant activity in a mouse model of poststroke depression. Biomed. Pharmacother. 99, 290-298. https://doi.org/10.1016/j. biopha.2018.01.073.

Naderi, N., Karponis, D., Mosahebi, A., Seifalian, A.M., 2018. Nanoparticles in wound healing; from hope to promise, from promise to routine. Front. Biosci. - Landmark 23, 1038-1059. https://doi.org/10.2741/4632.

Nafee, N., Youssef, A., El-Gowelli, H., Asem, H., Kandil, S., 2013. Antibiotic-free nanotherapeutics: hypericin nanoparticles thereof for improved in vitro and in vivo antimicrobial photodynamic therapy and wound healing. Int. J. Pharm. 454, 249-258. https://doi.org/10.1016/j.ijpharm.2013.06.067.

Najafizadeh, P., Hashemian, F., Mansouri, P., Farshi, S., Surmaghi, M.S., Chalangari, R., 2012. The evaluation of the clinical effect of topical St Johns wort (Hypericum perforatum L.) in plaque type psoriasis vulgaris: a pilot study. Australas. J. Dermatol. 53, 131-135. https://doi.org/10.1111/j.1440-0960.2012.00877.x.

Napoli, E., Siracusa, L., Ruberto, G., Carrubba, A., Lazzara, S., Speciale, A., Cimino, F., Saija, A., Cristani, M., 2018. Phytochemical profiles, phototoxic and antioxidant properties of eleven Hypericum species - a comparative study. Phytochemistry 152, 162-173. https://doi.org/10.1016/j.phytochem.2018.05.003.

Natural Cosmetics Market Size, Share, Trends | Industry Report, 2025. https://www.gr andviewresearch.com/industry-analysis/natural-cosmetics-market.

Nguyen Viet, D., Le Ba, V., Nguyen Duy, T., Pham Thi, V.A., Tran Thi, H., Le Canh, V.C. Bach Long, G., Kim, Y.H., Tuan, Anh, Le, H., 2019. Bioactive compounds from the aerial parts of Hypericum sampsonii. Nat. Prod. Res. 0, 1-3. https://doi.org/10.1080/ 14786419.2019.1586690.

Nogueira, T., Medeiros, M.A., Marcelo-Curto, M.J., García-Pérez, B.E., Luna-Herrera, J., Costa, M.C., 2013. Profile of antimicrobial potential of fifteen Hypericum species from Portugal. Ind. Crops Prod. 47, 126-131. https://doi.org/10.1016/j. indcrop.2013.03.005.

Nohynek, G.J., Borgert, C.J., Dietrich, D., Rozman, K.K., 2013. Endocrine disruption: fact or urban legend? Toxicol. Lett. 223, 295-305. https://doi.org/10.1016/j. toxlet.2013.10.022.

Nürk, N.M., Crockett, S.L., 2011. Morphological and phytochemical diversity among Hypericum species of the Mediterranean Basin. Med. Aromat. Plant Sci. Biotechnol. $5,14-28$.

Ozen, T., Ayan, A.K., Cirak, C., Kevseroglu, K., 2005. Total phenol content of some Hypericum species growing in Turkey. Chem. Nat. Compd. 41, 232-233. https://doi. org/10.1007/s10600-005-0120-0.

Öztürk, N., Korkmaz, S., Öztürk, Y., 2007. Wound-healing activity of St. John's Wort (Hypericum perforatum L.) on chicken embryonic fibroblasts. J. Ethnopharmacol. 111, 33-39. https://doi.org/10.1016/j.jep.2006.10.029.

Peron, G., Hošek, J., Rajbhandary, S., Pant, D.R., Dall'Acqua, S., 2019. LC-MSn and HRMS characterization of secondary metabolites from Hypericum japonicum Thunb. ex Murray from Nepalese Himalayan region and assessment of cytotoxic effect and inhibition of NF- $\mathrm{kB}$ and AP-1 transcription factors in vitro. J. Pharm. Biomed. Anal. 174, 663-673. https://doi.org/10.1016/j.jpba.2019.06.042.
Phaniendra, A., Jestadi, D.B., Periyasamy, L., 2015. Free radicals: properties, sources, targets, and their implication in various diseases. Indian J. Clin. Biochem. 30, 11-26. https://doi.org/10.1007/s12291-014-0446-0.

Pillaiyar, T., Manickam, M., Jung, S.H., 2017. Recent development of signaling pathways inhibitors of melanogenesis. Cell. Signal. 40, 99-115. https://doi.org/10.1016/j. cellsig.2017.09.004.

Pinto, M., Moraes, C.T., 2015. Mechanisms linking mtDNA damage and aging. Free Radic. Biol. Med. 85, 250-258. https://doi.org/10.1016/j. freeradbiomed.2015.05.005.

Plenagl, N., Seitz, B.S., Reddy Pinnapireddy, S., Jedelská, J., Brüßler, J., Bakowsky, U., 2018. Hypericin loaded liposomes for anti-microbial photodynamic therapy of grampositive Bacteria. Phys. Status Solidi Appl. Mater. Sci. 215, 1-6. https://doi.org/ 10.1002/pssa.201700837.

Rabanal, R.M., Arias, A., Prado, B., Hernández-Pérez, M., Sánchez-Mateo, C.C., 2002. Antimicrobial studies on three species of Hypericum from the Canary Islands. J. Ethnopharmacol. 81, 287-292. https://doi.org/10.1016/S0378-8741(02)000831.

Ramasamy, K., Shanmugam, M., Balupillai, A., Govindhasamy, K., Gunaseelan, S., Muthusamy, G., Robert, B., Nagarajan, R., 2017. Ultraviolet radiation-induced carcinogenesis: mechanisms and experimental models. J. Radiat. Cancer Res. 8, 4 https://doi.org/10.4103/0973-0168.199301.

Rittié, L., Fisher, G.J., 2002. UV-light-induced signal cascades and skin aging. Ageing Res. Rev. 1, 705-720. https://doi.org/10.1016/S1568-1637(02)00024-7.

Saddiqe, Z., Naeem, I., Maimoona, A., 2010. A review of the antibacterial activity of Hypericum perforatum L. J. Ethnopharmacol. 131, 511-521. https://doi.org/ 10.1016/j.jep.2010.07.034.

Sánchez-Mateo, C.C., Bonkanka, C.X., Rabanal, R.M., 2009. Hypericum grandifolium Choisy: a species native to Macaronesian Region with antidepressant effect. J. Ethnopharmacol. 121, 297-303. https://doi.org/10.1016/j.jep.2008.10.031.

Secchi, M., Castellani, V., Collina, E., Mirabella, N., Sala, S., 2016. Assessing ecoinnovations in green chemistry: life Cycle Assessment (LCA) of a cosmetic product with a bio-based ingredient. J. Clean. Prod. 129, 269-281. https://doi.org/10.1016/ j.jclepro.2016.04.073.

Sharma, K.V., Davids, L.M., 2012. Depigmentation in melanomas increases the efficacy of hypericin-mediated photodynamic-induced cell death. Photodiagn. Photodyn. Ther. 9, 156-163. https://doi.org/10.1016/j.pdpdt.2011.09.003.

Sharma, A.K., Taneja, G., Khanna, D., Rajput, S.K., 2015. Reactive oxygen species: friend or foe? RSC Adv. 5, 57267-57276. https://doi.org/10.1039/c5ra07927f.

Silva, A.R., Pinela, J., Dias, M.I., Calhelha, R.C., Alves, M.J., Mocan, A., García, P.A., Barros, L., Ferreira, I.C.F.R., 2020. Exploring the phytochemical profile of Cytinus hypocistis (L.) L. as a source of health-promoting biomolecules behind its in vitro bioactive and enzyme inhibitory properties. Food Chem. Toxicol. 136, 1110712 https://doi.org/10.1016/j.fct.2019.111071.

Souto, E.B., Baldim, I., Oliveira, W.P., Rao, R., Yadav, N., Gama, F.M., Mahant, S., 2020a. SLN and NLC for topical, dermal, and transdermal drug delivery. Expert Opin. Drug Deliv. 1-21. https://doi.org/10.1080/17425247.2020.1727883.

Souto, E.B., Silva, G.F., Dias-Ferreira, J., Zielinska, A., Ventura, F., Durazzo, A., Lucarini, M., Novellino, E., Santini, A., 2020b. Nanopharmaceutics: part II-production scales and clinically compliant production methods. Nanomaterials 10, 1-16. https://doi.org/10.3390/nano10030455.

Süntar, I.P., Akkol, E.K., Yilmazer, D., Baykal, T., Kirmizibekmez, H., Alper, M., Yeşilada, E., 2010. Investigations on the in vivo wound healing potential of Hypericum perforatum L. J. Ethnopharmacol. 127, 468-477. https://doi.org/ 10.1016/j.jep.2009.10.011.

Süntar, I., Akkol, E.K., Keleş, H., Oktem, A., Başer, K.H.C., Yeşilada, E., 2011. A novel wound healing ointment: a formulation of Hypericum perforatum oil and sage and oregano essential oils based on traditional Turkish knowledge. J. Ethnopharmacol. 134, 89-96. https://doi.org/10.1016/j.jep. 2010.11.061.

Takao, K., Kubota, Y., Kamauchi, H., Sugita, Y., 2019. Synthesis and biological evaluation of pyrano[4,3-b][1] benzopyranone derivatives as monoamine oxidase and cholinesterase inhibitors. Bioorg. Chem. 83, 432-437. https://doi.org/10.1016/ j.bioorg.2018.11.004.

Takó, M., Kerekes, E.B., Zambrano, C., Kotogán, A., Papp, T., Krisch, J., Vágvölgyi, C., 2020. Plant phenolics and phenolic-enriched extracts as antimicrobial agents against food-contaminating microorganisms. Antioxidants 9, 165. https://doi.org/10.3390/ antiox9020165.

Tampa, M., Sarbu, M.I., Matei, C., Mitran, C.I., Mitran, M.I., Caruntu, C., Constantin, C., Neagu, M., Georgescu, S.R., 2019. Photodynamic therapy: a hot topic in dermatooncology (Review). Oncol. Lett. 17, 4085-4093. https://doi.org/10.3892/ ol.2019.9939.

Tanaka, N., Takaishi, Y., 2006. Xanthones from Hypericum chinense. Phytochemistry 67, 2146-2151. https://doi.org/10.1016/j.phytochem.2006.05.043.

Tanaka, N., Okasaka, M., Ishimaru, Y., Takaishi, Y., Sato, M., Okamoto, M., Oshikawa, T., Ahmed, S.U., Consentino, L.M., Lee, K.H., 2005. Biyouyanagin A, an anti-HIV agent from Hypericum chinense L. var. salicifolium. Org. Lett. 7, 2997-2999. https://doi. org/10.1021/ol050960w.

Taofiq, O., González-Paramás, A.M., Martins, A., Barreiro, M.F., Ferreira, I.C.F.R., 2016a. Mushrooms extracts and compounds in cosmetics, cosmeceuticals and nutricosmetics-A review. Ind. Crops Prod. 90, 38-48. https://doi.org/10.1016/j indcrop.2016.06.012.

Taofiq, O., Martins, A., Barreiro, M.F., Ferreira, I.C.F.R., 2016b. Anti-inflammatory potential of mushroom extracts and isolated metabolites. Trends Food Sci. Technol. 50, 193-210. https://doi.org/10.1016/j.tifs.2016.02.005.

Tobin, D.J., 2016. Introduction to skin aging. J. Tissue Viability. https://doi.org/ 10.1016/j.jtv.2016.03.002. 
Tocci, N., Weil, T., Perenzoni, D., Narduzzi, L., Madriñán, S., Crockett, S., Nürk, N.M., Cavalieri, D., Mattivi, F., 2018. Phenolic profile, chemical relationship and antifungal activity of Andean Hypericum species. Ind. Crops Prod. 112, 32-37. https://doi.org/10.1016/j.indcrop.2017.10.030.

Tusevski, O., Petreska Stanoeva, J., Stefova, M., Pavokovic, D., Gadzovska Simic, S., 2014. Identification and quantification of phenolic compounds in Hypericum perforatum L. transgenic shoots. Acta Physiol. Plant. 36, 2555-2569. https://doi.org/ 10.1007/s11738-014-1627-4.

Tusevski, O., Krstikj, M., Stanoeva, J.P., Stefova, M., Gadzovska Simic, S., 2018. Phenolic profile and biological activity of Hypericum perforatum L.: can roots be considered as a new source of natural compounds? S. Afr. J. Bot. 117, 301-310. https://doi.org/ 10.1016/j.sajb.2018.05.030.

Vaiserman, A.M., Lushchak, O.V., Koliada, A.K., 2016. Anti-aging pharmacology: promises and pitfalls. Ageing Res. Rev. 31, 9-35. https://doi.org/10.1016/j. arr.2016.08.004.

Valentão, P., Carvalho, M., Fernandes, E., Carvalho, F., Andrade, P.B., Seabra, R.M., Bastos, M.D.L., 2004. Protective activity of Hypericum androsaemum infusion against tert-butyl hydroperoxide-induced oxidative damage in isolated rat hepatocytes. J. Ethnopharmacol. 92, 79-84. https://doi.org/10.1016/j.jep.2004.02.004.

Varvaresou, A., Papageorgiou, S., Tsirivas, E., Protopapa, E., Kintziou, H., Kefala, V., Demetzos, C., 2009. Self-preserving cosmetics. Int. J. Cosmet. Sci. 31, 163-175. https://doi.org/10.1111/j.1468-2494.2009.00492.x.

Vieira, R., Severino, P., Nalone, L.A., Souto, S.B., Silva, A.M., Lucarini, M., Durazzo, A., Santini, A., Souto, E.B., 2020. Sucupira oil-loaded nanostructured lipid carriers (NLC): lipid screening, factorial design, release profile, and cytotoxicity. Molecules 25, 685. https://doi.org/10.3390/molecules25030685.

Wu, F., Li, H., Zhao, L., Li, X., You, J., Jiang, Q., Li, S., Jin, L., Xu, Y., 2013. Protective effects of aqueous extract from Acanthopanax senticosus against corticosteroneinduced neurotoxicity in PC12 cells. J. Ethnopharmacol. 148, 861-868. https://doi. org/10.1016/j.jep.2013.05.026.

Xu, W.J., Zhu, M..Di, Wang, X.B., Yang, M.H., Luo, J., Kong, L.Y., 2015. Hypermongones A-J, rare methylated polycyclic polyprenylated acylphloroglucinols from the flowers of Hypericum monogynum. J. Nat. Prod. 78, 1093-1100. https://doi.org/10.1021/ acs.jnatprod.5b00066.

Xu, W.J., Luo, J., Li, R.J., Yang, M.H., Kong, L.Y., 2017. Furanmonogones A and B: two rearranged acylphloroglucinols with a 4,5-: Seco -3(2 H)-furanone core from the flowers of Hypericum monogynum. Org. Chem. Front. 4, 313-317. https://doi.org/ 10.1039/c6qo00620e.
Xu, W.J., Tang, P.F., Lu, W.J., Zhang, Y.Q., Wang, X.B., Zhang, H., Luo, J., Kong, L.Y., 2019. Hyperberins a and B, type B polycyclic polyprenylated acylphloroglucinols with bicyclo[5.3.1] hendecane core from Hypericum beanii. Org. Lett. 21, 8558-8562. https://doi.org/10.1021/acs.orglett.9b03098.

Yaşar, Ș.N., Can, Ö.D., Öztürk, N., Sagratini, G., Ricciutelli, M., Vittori, S., Maggi, F., 2013. Central nervous system activities of Hypericum origanifolium extract via GABAergic and opioidergic mechanisms. Phyther. Res. 27, 877-884. https://doi. org/10.1002/ptr.4801.

Ye, Y., Jiang, N., Yang, X., Xu, G., 2020. Polycyclic polyprenylated acylphloroglucinol with an unprecedented spirocyclic core from Hypericum patulum. Chin. Chem. Lett. https://doi.org/10.1016/j.cclet.2020.04.028.

Yücel, A., Kan, Y., Yesilada, E., Akın, O., 2017. Effect of St.John's wort (Hypericum perforatum) oily extract for the care and treatment of pressure sores; a case report. J. Ethnopharmacol. 196, 236-241. https://doi.org/10.1016/j.jep.2016.12.030.

Zdunic, G., Godjevac, D., Savikin, K., Petrovic, S., 2017. Comparative analysis of phenolic compounds in seven Hypericum species and their antioxidant properties. Nat. Prod. Commun. 12, 1934578X1701201 https://doi.org/10.1177/ 1934578X1701201140.

Zhang, M., Zhou, J., Wang, L., Li, B., Guo, J., Guan, X., Han, Q., Zhang, H., 2014. Caffeic acid reduces cutaneous tumor necrosis factor alpha (TNF- $\alpha$ ), IL-6 and IL- $1 \beta$ levels and ameliorates skin edema in acute and chronic model of cutaneous inflammation in mice. Biol. Pharm. Bull. 37, 347-354. https://doi.org/10.1248/bpb.b13-00459.

Zhang, J.S., Huang, J.L., Zou, Y.H., Liu, X., Ahmed, A., Tang, G.H., Yin, S., 2017. Novel degraded polycyclic polyprenylated acylphloroglucinol and new polyprenylated benzophenone from Hypericum sampsonii. Phytochem. Lett. 21, 190-193. https:// doi.org/10.1016/j.phytol.2017.06.023.

Zhang, R., Ji, Y., Zhang, X., Kennelly, E.J., Long, C., 2020. Ethnopharmacology of Hypericum species in China: a comprehensive review on ethnobotany, phytochemistry and pharmacology. J. Ethnopharmacol. https://doi.org/10.1016/j. jep.2020.112686.

Zhou, Z.B., Zhang, Y.M., Pan, K., Luo, J.G., Kong, L.Y., 2014. Cytotoxic polycyclic polyprenylated acylphloroglucinols from Hypericum attenuatum. Fitoterapia 95, 1-7. https://doi.org/10.1016/j.fitote.2014.02.011.

Zorzetto, C., Sánchez-Mateo, C.C., Rabanal, R.M., Lupidi, G., Petrelli, D., Vitali, L.A., Bramucci, M., Quassinti, L., Caprioli, G., Papa, F., Ricciutelli, M., Sagratini, G., Vittori, S., Maggi, F., 2015. Phytochemical analysis and in vitro biological activity of three Hypericum species from the Canary Islands (Hypericum reflexum, Hypericum canariense and Hypericum grandifolium). Fitoterapia 100, 95-109. https://doi.org/ 10.1016/j.fitote.2014.11.013. 